Studia Judaica 24 (2021), nr 1 (47), s. 175-211

doi:10.4467/24500100STJ.21.007.14609

Renata Piątkowska (iD https://orcid.org/0000-0003-3101-2488

\title{
Artystki i miłośniczki sztuki - kobiety w żydowskim życiu artystycznym międzywojennej Warszawy. W kręgu Żydowskiego Towarzystwa Krzewienia Sztuk Pięknych
}

\author{
ARTISTS AND ART LOVERS: WOMEN IN THE JEWISH ARTISTIC LIFE \\ OF INTERWAR WARSAW. IN THE CIRCLE OF THE JEWISH SOCIETY \\ FOR THE ENCOURAGEMENT OF FINE ARTS
}

\begin{abstract}
Research on Jewish artistic life in interwar Warsaw, especially in the context of the activities of the Jewish Society for the Encouragement of Fine Arts (Żydowskie Towarzystwo Krzewienia Sztuk Pięknych), reveals active and numerous participation of women, both artists and art lovers (by and large a group of professionals, bourgeois, political and social activists, Jewish art collectors). In the article, special attention is paid to Tea Arciszewska and Diana Eigerowa, a collector and philanthropist, the founder of the Samuel Hirszenberg scholarship for students of the Academy of Fine Arts in Warsaw.

The author, using selected examples, discusses the role of artists in the artistic community, their individual exhibitions in the Jewish Society for the Encouragement of Fine Arts (Stanisława Centnerszwerowa, Regina Mundlak), a group of young artists living in Paris (Alicja Hohermann, Zofia Bornstein, Pola Lindenfeld, Estera Karp), as well as a circle of art lovers and patrons, some of whom—such as Tea Arciszewska and Paulina Apenszlak-also dealt with art criticism.
\end{abstract}

Keywords: fine arts, women artists, women, Jewish artistic life, Jewish Society for the Encouragement of Fine Arts, Warsaw.

Słowa kluczowe: sztuki piękne, artystki, kobiety, żydowskie życie artystyczne, Żydowskie Towarzystwo Krzewienia Sztuk Pięknych, Warszawa. 
W żydowskim życiu artystycznym międzywojennej Warszawy kobiety były obecne głównie jako miłośniczki sztuki - odwiedzające wystawy, uczestniczące w prelekcjach, wykładach, w Balach Sztuki Żydowskiej. Najrzadziej natomiast jako krytyczki sztuki czy członkinie władz dwóch instytucji żydowskiego życia artystycznego w Warszawie: Żydowskiego Towarzystwa Krzewienia Sztuk Pięknych (ŻTKSP) i Stowarzyszenia Żydowskich Artystów Plastyków w Polsce (SŻAPwP), oraz jako artystki pokazujące swe prace na wystawach organizowanych przez Towarzystwo i Stowarzyszenie.

Do tej pory nie prowadzono badań nad miejscem kobiet w żydowskim życiu artystycznym w Warszawie. Jednak liczna ich obecność i zaangażowanie wymagają odrębnego spojrzenia, ustalenia i uporządkowania podstawowych faktów: ile kobiet było we władzach obydwu organizacji, ile artystek brało udział w wystawach, ile z nich dostało szansę na indywidualną prezentację swego dorobku. To spojrzenie pozwala też dostrzec niezauważalną w oficjalnym dyskursie, ale istotną z punktu widzenia działalności obydwu organizacji, obecność kobiet jako osób wspierających obie instytucje artystyczne. W artykule przedstawię wybitne miłośniczki kobiety zaangażowane w rozwój żydowskiego życia artystycznego - oraz te artystki, które miały ekspozycje indywidualne w ŻTKSP (SŻAPwP programowo nie organizowało wystaw indywidualnych, lecz tylko prezentacje zbiorowe).

Po powstaniu II Rzeczypospolitej okazało się, że Żydzi polscy - największa w Europie społeczność żydowska - mają nie tylko chęci, ale i prawne możliwości budowania życia narodowego zarówno w sferze politycznej (rozwój partii politycznych i udział w życiu politycznym w kraju) i społecznej (m.in. szkolnictwo w językach narodowych: żydowskim i hebrajskim, żydowskie organizacje zawodowe, sportowe, turystyczne), jak i kulturalnej (prasa żydowska w języku polskim, żydowskim i hebrajskim, teatr i film w jidysz, instytucje życia artystycznego). Nie było to łatwe zadanie. $Z$ jednej strony za zróżnicowaniem społeczności żydowskiej szły różnorakie oczekiwania wobec kultury narodowej - inne w przypadku społeczności religijnych, inne w przypadku kultury świeckiej znajdującej wsparcie w ideach politycznych (syjonizm, jidyszyzm, bundyzm), które decydowały także o wyborze języka narodowego (jidysz bądź hebrajskiego). Z drugiej strony trzeba było znaleźć skuteczne sposoby działania, co wymagało odnalezienia się 
w rzeczywistości odrodzonej Polski ${ }^{1}$. Wśród wielu zmian, jakie przyniosła niepodległość, jedną z najważniejszych było przyznanie praw obywatelskich kobietom, ale w Warszawie Żydówki nadal nie mogły brać udziału w wyborach do władz gminy żydowskiej². Od początku kobiety aktywnie też uczestniczyły w procesie budowy żydowskiego życia artystycznego, choć ich rola jest pomijana i marginalizowana, zarówno jeśli chodzi o twórczość artystek, jak i uczestnictwo kobiet w kulturze.

Odzyskanie niepodległości i powstanie Polski jako państwa „zorientowanego narodowo" 3 miały decydujący wpływ na życie zamieszkujących ją mniejszości, które przez środowiska prawicowe i konserwatywne postrzegane były jako grupy nie tylko niepopierające polskiej państwowości, lecz niekiedy wręcz zagrażające bytowi narodowemu ${ }^{4}$. W świecie sztuki twórcy, podobnie jak cała społeczność żydowska, musieli się zmierzyć z lekceważeniem, niechęcią, odrzuceniem i wykluczaniem z polskiego (generalnego) życia artystycznego. Dla środowisk artystycznych sztuka była „środkiem” do wyrażenia zbiorowych dążeń narodowych, nie przestawała być jednak celem samym w sobie. W 1922 r., w pierwszą rocznicę otwarcia Wystawy Prac Artystów Żydowskich, Jakub Apenszlak zadawał pytanie:

Co to jest sztuka żydowska? Czy istnieje ? $^{5}$ I odpowiadał: Jako jeden z inicjatorów wystawy stwierdzam, że nie śniliśmy nawet o zobrazowaniu sztuki żydowskiej. Nazwaliśmy początkowo nasze przedsięwzięcie „wystawą prac artystów żydowskich". Sztuki nie bierzmowaliśmy, mówiliśmy tylko o artystach. Ale czuliśmy, że istnieje, bliżej może nieuświadomiona, konieczność takiej właśnie wystawy ${ }^{6}$.

Owa „konieczność” - rozwój żydowskiego życia narodowego - która sprawiła, że artyści-Żydzi i artystki-Żydówki wystawiający w warszawskich salonach sztuki decydowali się na organizowanie oddzielnych ekspozycji, wpisywała się w szerszy nacjonalistyczny program kultury Żydów w Polsce.

${ }^{1}$ Anna Landau-Czajka, Polska to nie oni. Polska i Polacy w polskojęzycznej prasie żydowskiej II Rzeczypospolitej, Warszawa 2015, s. 68-95.

${ }^{2}$ Szeroko omawia tę kwestię Rafał Żebrowski - zob. Rafał Żebrowski, Żydowska Gmina Wyznaniowa w Warszawie 1918-1939. W kręgu polityki, Warszawa 2012, s. 107-135.

${ }_{3}^{3}$ Rogers Brubaker, Nacjonalizm inaczej. Struktura narodowa i kwestie narodowe w nowej Europie, tłum. Jan Łuczyński, Warszawa-Kraków 1998, s. 80-85, 99-135.

${ }^{4}$ Roman Wapiński, Narodowa Demokracja, 1893-1939. Ze studiów nad dziejami myśli nacjonalistycznej, Wrocław 1980, s. 244-245.

5 Jakub Apenszlak, Z powodu rocznicy powstania żyd. wystawy sztuki, „Nasz Kurier” 3 (1922), nr 144, s. 4.

${ }^{6}$ Tamże. 
W świecie sztuki istotnymi czynnikami w dążeniach do autonomizacji żydowskiego życia artystycznego były także antysemityzm i ofensywa polskiego nacjonalizmu ${ }^{7}$. Od początku autonomia ta nie oznaczała separowania się od generalnego życia artystycznego w Polsce (głosy to postulujące dochodziły natomiast z prasy endeckiej), choć twórcy nie zawsze czuli się tego życia pełnoprawnymi uczestnikami. Wkrótce się okazało, że najważniejsze cele tej niezależnej działalności na polu sztuki, oprócz wsparcia dla artystów i artystek, to wzmacnianie wspólnoty narodowej, dumy i tożsamości oraz wprowadzenie - tradycyjnej w większości - społeczności żydowskiej w nowoczesność 8 .

\section{Wokół instytucji}

\section{W kręgu władz}

Kiedy w 1923 r. ukonstytuowało się Żydowskie Towarzystwo Krzewienia Sztuk Pięknych ${ }^{9}$, wśród jego założycieli byli tylko mężczyźni: Jakub Apenszlak $^{10}$, Józef Dickstein ${ }^{11}$, Feliks Frydman ${ }^{12}$, Mojżesz Koerner ${ }^{13}$,

${ }^{7}$ Dariusz Konstantynów, „Sztuka żydowska”. O jednym z pojęć nacjonalistycznej krytyki artystycznej w Polsce międzywojennej, „Kwartalnik Historii Żydów” 65 (2016), nr 2, s. 475-495.

${ }_{8}$ Trzeba pamiętać, że nie wszyscy artyści pochodzaç z rodzin żydowskich brali udział w wystawach żydowskich. Dotyczy to zwłaszcza twórców zasymilowanych, często także religijnie, jak np. Henryk Kuna, Roman Kramsztyk czy Jan Gotard.

${ }^{9}$ Statut Żydowskiego Towarzystwa Krzewienia Sztuk Pięknych został zatwierdzony przez Ministerstwo Spraw Wewnętrznych 10 marca 1923 r. Statut Żydowskiego Towarzystwa Krzewienia Sztuk Pięknych w Warszawie, Warszawa 1924, s. 3.

${ }^{10}$ O Jakubie Apenszlaku zob. m.in.: Katrin Steffen, Jüdische Polonität: Ethnizität und Nation im Spiegel der polnischsprachigen jüdischen Presse 1918-1939, Gottingen 2004, s. 369-379; Joanna Godlewska, Polski Żyd. Jakub Apenszlak jako krytyk teatralny, „Pamiętnik Teatralny" 41 (1992), z. 1-4, s. 127-134; Alina Molisak, Zionism in Polish, or on a Few of Jakub Appenszlak's Texts, [w:] Polish and Hebrew Literature and National Identity, red. Alina Molisak, Shoshana Ronen, Warszawa 2010, s. 146-159; Renata Piątkowska, Jakub Apenszlak jako wspóttwórca Żydowskiego Towarzystwa Krzewienia Sztuk Pięknych, „Midrasz” 14 (2010), nr 6, s. 55-61.

11 Józef Dickstein (Dyksztejn), dziennikarz publikujący pod pseudonimem M. Walwild.

${ }_{12}$ MT [Magdalena Tarnowska], Feliks Frydman, [w:] Polski słownik judaistyczny. Dzieje. Kultura. Religia. Ludzie, red. Zofia Borzymińska, Rafał Żebrowski, Warszawa 2003, t. 1, s. 449-450; Jerzy Malinowski, Malarstwo i rzeźba Żydów polskich w XIX i XX wieku, Warszawa 2000 , s. 241-242.

${ }_{13}$ RŻ [Rafał Żebrowski], Koerner Mojżesz, [w:] Polski słownik judaistyczny..., t. 1, s. 794-795; Postowie i senatorowie Rzeczypospolitej Polskiej 1919-1939. Słownik biograficzny, t. 3, oprac. Piotr Majewski, red. Grzegorz Mazur, Warszawa 2005, s. 145-146. 
Gerszon Lewin ${ }^{14}$, Szaja Lebenbaum ${ }^{15}$, Józef Mieses ${ }^{16}$, Naftal Prywes ${ }^{17}$, Abraham Ostrzega ${ }^{18}$, Władysław Weintraub ${ }^{19}$. Jednak najważniejsze cele Towarzystwa - „rozwój sztuk pięknych” i „krzewienie zamiłowania do sztuk pięknych wśród ludności żydowskiej w Polsce" ${ }^{20}$ - bliskie były także kobietom, zarówno artystkom, jak i miłośniczkom sztuki, chociaż w początkowym okresie nie znalazły się one w publicznym gronie działaczy tej instytucji żydowskiego życia artystycznego. Nie znaczy to oczywiście, że były nieobecne. W 1921 r. w Komitecie do spraw Sztuki Żydowskiej była Stanisława Centnerszwerowa ${ }^{21}$. Malarka, mimo zaangażowania w działalność Komitetu - w 1922 r. czuwała nad stroną dekoracyjno-zdobniczą działu graficznego V Żydowskiej Wystawy Sztuki ${ }^{22}$ - nie znalazła się wśród założycieli ŻTKSP. W dwudziestoleciu międzywojennym patriarchalny dyskurs w społeczności żydowskiej, także w sferze sztuki, nadal był aktualny. Jednakże uważna lektura prasy, wspomnień i literatury pięknej oraz analiza działalności organizacji ŻTKSP i - w mniejszym stopniu - SŻAPwP pokazują, że kobiety od początku uczestniczyły w tych działaniach, a ich rola jako artystek, miłośniczek sztuki, a także konsumentek kultury nie była tak nieistotna, jak wynikałoby to ze znanych źródeł. Podobnie było w generalnym polu sztuki w Warszawie i w całej II Rzeczypospolitej, gdzie - zwłaszcza w sferze oficjalnej - dominowali mężczyźni. Do zarządu Towarzystwa Zachęty Sztuk Pięknych dopiero w 1920 r. weszły dwie kobiety: Zofia Stankiewiczówna (ze strony artystek) oraz Emilia Herse

${ }_{14}$ ZB [Zofia Borzymińska], Lewin Gerszon, [w:] Polski stownik judaistyczny..., t. 2, s. 3839; Piotr Szarejko, Stownik lekarzy polskich XIX wieku, t. 4, Warszawa 1997, s. 237-238.

${ }_{15}$ Dziennikarz „Naszego Kuriera” i „Naszego Przeglądu”.

${ }_{16}$ Marian Fuks, Mieses Józef, [w:] Polski Stownik Biograficzny, t. 21, red. Emanuel Rostworowski, Wiesława Albrecht i in., Wrocław-Warszawa 1976, s. 29; Gershon Bacon, Mieses Józef, [w:] The YIVO Encyclopedia of Jews in Eastern Europe, red. Gershon David Hundert, YIVO | Mieses, Józef (yivoencyclopedia.org) [dostęp: 12 sierpnia 2021].

${ }_{17}$ Naftal Prywes - przemysłowiec, filantrop.

18 Abraham Ostrzega podał tę informację w nocie biograficznej opublikowanej w: $C z y$ wiesz kto to jest?, red. Stanisław Łoza, Warszawa 1938, s. 544. Zob. Urszula Makowska, Ogrody Abrahama Ostrzegi, „Pamiętnik Sztuk Pięknych” 4 (2017), nr 12, s. 13-30.

19 Statut..., s. 16.

${ }^{20}$ Tamże, s. 3-4.

${ }^{21}$ „Nasz Kurier” 2 (1921), nr 121, s. 3. Członkami Komitetu obok Centnerszwerowej byli: Jakub Apenszlak, Henryk Berlewi, Henryk Gotlib, Maurycy Minkowski, Abraham Ostrzega i Michał Weichert.

22 „Nasz Kurier” 3 (1922), nr 234, s. 5. 
jako miłośniczka. Natomiast w Radzie powołanego w 1930 r. Instytutu Propagandy Sztuki (IPS) zasiadali sami mężczyźni²3.

Na początek warto krótko przybliżyć cele i zadania największej instytucji żydowskiego życia artystycznego w Warszawie. Zwięzłe zapisy w Statucie Żydowskiego Towarzystwa Krzewienia Sztuk Pięknych rozwinięto w programowym artykule opublikowanym kilka lat później w krakowskim „Nowym Dzienniku”. Podkreślano w nim stanowczo, że Towarzystwo

nie jest i nie ma [...] być jeszcze jednem zrzeszeniem malarzy, żadnym ekskluzywnym cechem zawodowym, ale ma za cel krzewić i szerzyć wśród społeczeństwa żydowskiego sztukę [...] pomóc $w$ wychowaniu społeczeństwa ku pięknu, [...] wydobyć $z$ naszego społeczeństwa drzemiące $w$ niem sity $i$ wielkie możliwości także $w$ zakresie plastyki $i^{24}$.

Według Statutu „Członkiem Stowarzyszenia może zostać każda osoba bez różnicy płci”25. Nie znamy ani liczby, ani listy członków - w 1926 r. było ich $376^{26}$. W latach dwudziestych stanowisko prezesa piastowali na przemian Jakub Apenszlak i dr Izaak Lejpuner (w tym czasie Lejpuner był zazwyczaj wiceprezesem). Zarząd decydował o gospodarowaniu majątkiem i polityce finansowej Towarzystwa. Ponadto miał prawo zawierać umowy, by podnosić jego kapitał, przyjmować darowizny i zapisy testamentowe. Decydował też o składach jury.

Tylko dwie kobiety odnajdujemy we władzach Towarzystwa. W latach 1926-1933 członkinią Zarządu była Tea Arciszewska (1890-1962) - egeria żydowskich salonów, gwiazda scen jidyszowych; jako Miriam Izraels była ulubioną aktorką I. L. Pereca (il. 1). W latach 1926-1931 razem z Dawidem Hermanem prowadziła teatr miniatur „Azazel”27. Znawczyni sztuki, pisywała także relacje z wystaw ŻTKSP (m.in. do „Naszego Przeglądu”"28).

23 Joanna Sosnowska, Poza kanonem. Sztuka polskich artystek 1880-1939, Warszawa 2003, s. 193-195.

${ }^{24}$ Cele Żydowskiego Towarzystwa Szerzenia Sztuk Pięknych, „Nowy Dziennik” 12 (1930), nr 43, s. 9. Wyróżnienia w cytacie - jak w oryginalnym tekście.

${ }^{25}$ Statut..., s. 6.

${ }^{26}$ Finf jor ekzistenc fun der id. kunst ojssztelung, „Literarisze Bleter” 3 (1926), nr 126, s. 658 .

27 Tea Arciszewska, I. L. Perec mont zajn teater (fun majne zichrones un refleksn), [w:] Almanach. Arojgegebn durch Farajn fun Jidiszer Literatn un Zurnalistn in Frankrajch, Pariz 1955, s. 73-80; Aviv Livnat, Far undzere kinstler: Tea Arciszewska and the Jewish Artists, [w:] Art in Jewish Society, red. Jerzy Malinowski, Renata Piątkowska, Małgorzata Stolarska-Fronia, Tamara Sztyma, Warszawa-Toruń 2016, s. 25-37.

${ }_{28}$ Tea Arciszewska, Refleksje z wystawy Henryka Berlewiego, „Nasz Przegląd” 3 (1925), nr 107, s. 6; taż, Refleksje z wystawy zbiorowej artystów żydowskich, „Nasz Przegląd” 4 (1926), 


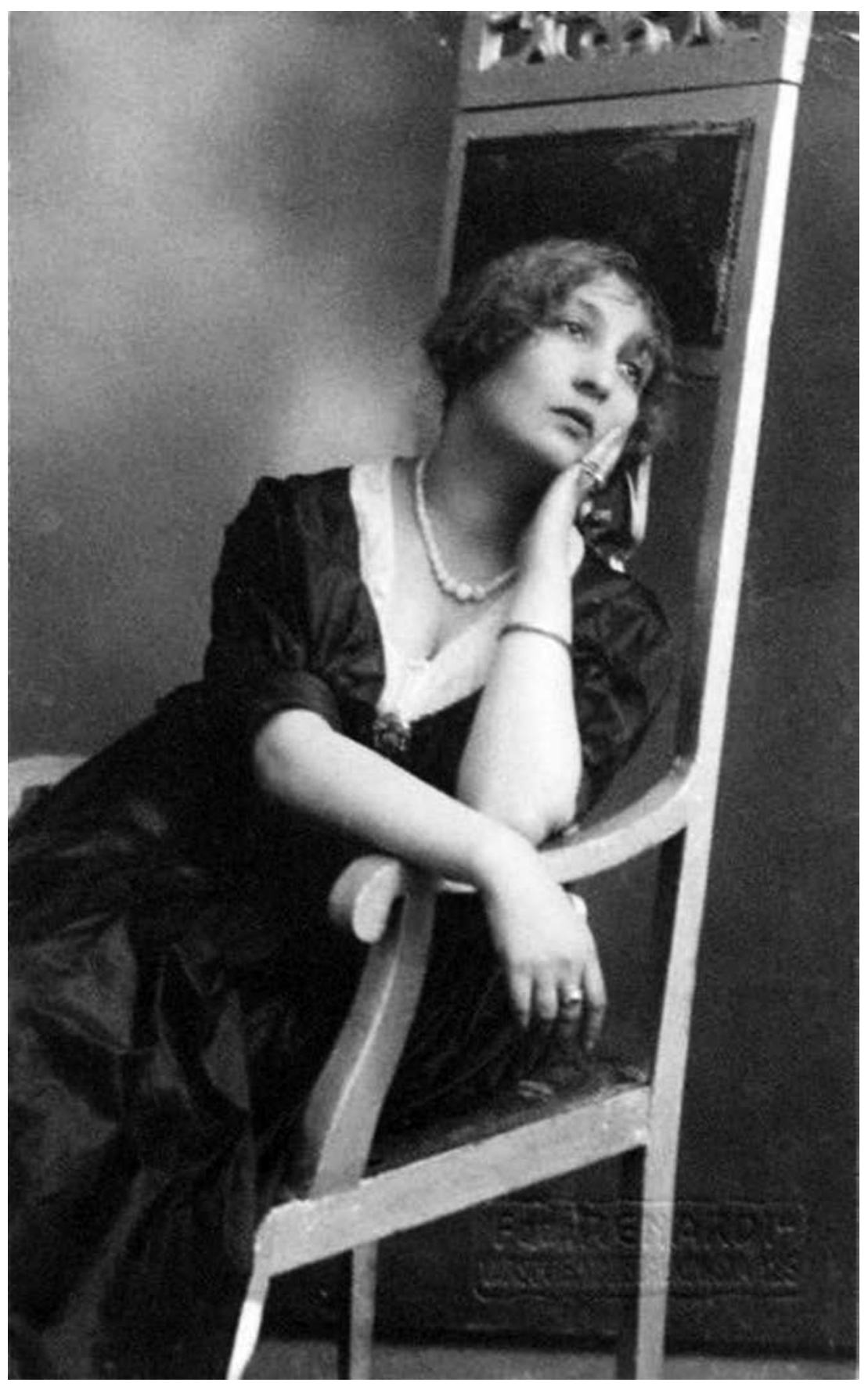

Il. 1. Tea Arciszewska, Warszawa 1923, fotografia, autor nieznany, kolekcja prywatna, Paryż. 
Świat sztuki był jej bliski: siostra Sara Lipska (Lipszyc) ${ }^{29}$ od 1904 r. studiowała w warszawskiej Szkole Sztuk Pięknych, podobnie jak pierwszy mąż Tei, rzeźbiarz Ber Kratka. Ich burzliwe małżeństwo nie przetrwało; Tea miała jeszcze trzech mężów, ostatnim był poślubiony po wojnie w Paryżu pisarz Efraim Kaganowski.

Sara i Tea (używająca imienia Tocia, Tocza) urodziły się w zamożnej rodzinie chasydzkiej w Mławie, dorastały w Warszawie. Ich domowym językiem był żydowski, którym też Tea posługiwała się w pracy twórczej w teatrze i literaturze ${ }^{30}$; wiemy jednak, że siostry Lipskie swobodnie mówiły po polsku. Ewa Ziembińska - autorka monografii Sary Lipskiej - uważa, iż „fakt, że zarówno Sara, jak i jej siostra Tea wybrały świat artystyczny jako drogę do realizacji własnych ambicji zawodowych, świadczy o szerokich horyzontach rodziców, a przede wszystkim o liberalnym podejściu ojca w kwestii wychowania dzieci" ${ }^{\prime 1}$. Siostry pozostawały w serdecznych stosunkach do śmierci Tei w 1962 r. (obydwie mieszkały wówczas w Paryżu) ${ }^{32}$.

Tea Arciszewska była właścicielką interesującej kolekcji sztuki współczesnej, w której oprócz dzieł siostry znajdowały się obrazy Maurycego Mędrzyckiego (później Maurice'a Mendjizky'ego) i Józefa Seidenbeutla oraz rzeźby Henryka Glicensteina i Bera Kratki. W 1921 r. wypożyczyła je na [I] Wystawę Prac Artystów Żydowskich ${ }^{33}$ (il. 2). W następnych latach kolekcja powiększała się o prace artystów młodszego pokolenia. W 1932 r. na wystawie Estetyka w życiu codziennem pokazano metaloplastyki Ariego Merzera z jej zbiorów ${ }^{34}$. Arciszewska już wcześniej była mecenaską tego młodego rzeźbiarza, niestrudzoną propagatorką jego twórczości, co potwierdza (ironicznie) Melech Rawicz:

nr 225, s. 8; taż, Refleksje z Wystawy Zbiorowej Prac Artystów Żydowskich, „Nasz Przegląd” 7 (1929), nr 150, s. 8.

${ }^{29}$ Ewa Ziembińska, Sara Lipska. Artystka wszechstronna, Warszawa 2020, s. 38-43 (mps, praca doktorska napisana pod kierunkiem prof. dr hab. Joanny M. Sosnowskiej w Instytucie Sztuki Polskiej Akademii Nauk).

${ }^{30}$ Tea Arciszewska, Miriaml, Pariz 1959.

${ }^{31}$ Ziembińska, Sara Lipska..., s. 36.

32 Tamże, s. 42.

${ }_{33}$ Katalog Wystawy Prac Artystów Żyd. Warszawa Gmina Lato 1921, Warszawa [1921]. Do Tei Arciszewskiej należał Portret $p$. K. autorstwa Sary, natomiast druga jej praca, Portret kobiecy, pochodziła z kolekcji Samuela Goldflama. Prace Józefa Seidenbeutla ze zbiorów Arciszewskiej pokazane zostały także na pośmiertnej wystawie artysty: Wystawa pośmiertna prac b. p. Józefa Seidenbeutla. Katalog wydany i ułożony przez M. i E. Seidenbeutlów, Warszawa [1923], poz. kat. 5-6.

${ }^{34}$ Wystawa p.n. „Estetyka w życiu codziennem”. LXVI, wrzesień 1932, Żydowskie Towarzystwo Krzewienia Sztuk Pięknych, [kat. wystawy], Warszawa [1932], s. 10-12. 


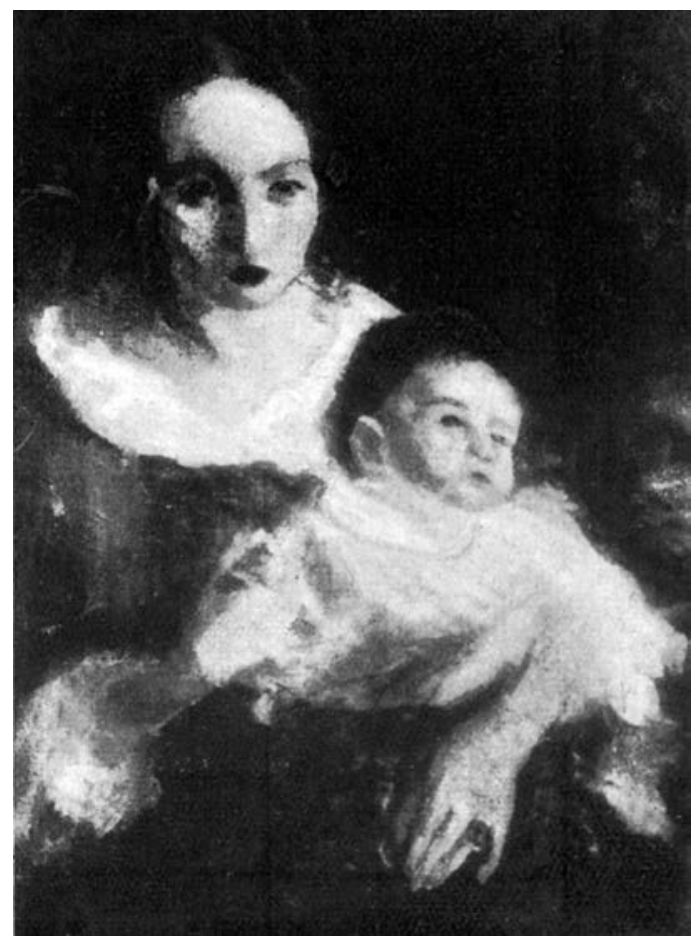

Il. 2. Józef Seidenbeutel, Matka z dzieckiem z kolekcji Tei Arciszewskiej, fot. z: Wystawa pośmiertna prac b. p. Józefa Seidenbeutla. Katalog wydany i ułożony przez M. i E. Seidenbeutlów, Warszawa [1923].

Pewnego pięknego dnia do Związku Literatów przyszła wielka koneserka sztuki Tocza Arciszewska, siostra wszystkich żydowskich artystów. Swoje wielkie dziedzictwo czerpie z czasów Pereca w Warszawie; a na jej stale lekko zaciśniętych, jakby gotowych na pocałunek ustach jedno słowo „Arie”... nowy talent, nie tylko talent, ale i geniusz, nie tylko geniusz, ale żydowski geniusz ${ }^{35}$.

Tea opowiadała o talencie Merzera, ale również w 1928 r. zorganizowała mu wystawę we własnym mieszkaniu. Dzięki pieniądzom zebranym ze sprzedaży prac młody artysta mógł pojechać do Paryża ${ }^{36}$.

Dopiero w ostatnim czasie Tea Arciszewska przypominana jest nie tylko jako młodociana skandalistka, jak przedstawił ją we wspomnieniach

${ }_{35}$ Melech Rawicz, Majn leksikon, t. 3, Montreal 1958, s. 270 (thum. cytatu - Renata Piątkowska).

${ }^{36}$ Livnat, Far undzere kinstler..., s. 31. 
Jechiel Jeszaja Trunk ${ }^{37}$, lecz także jako wybitna indywidualność polsko-żydowskiej sceny kulturalnej, dziedziczka Perecowej idei krzewienia kultury żydowskiej. Jej zaangażowanie w działalność Towarzystwa oraz tworzenie kolekcji sztuki artystów żydowskich trzeba uznać za jeden z elementów konstruowania nowoczesnej żydowskiej tożsamości społecznej i narodowej.

Malarka Bella Natansonowa (?- po 1945?) ${ }^{38}$ została wybrana do Zarządu Towarzystwa w drugiej połowie lat trzydziestych ${ }^{39}$. Zapewne ten fakt zdecydował, że w październiku 1937 r. swą pierwszą indywidualną wystawę pokazała w Salonie Sztuki Czesława Garlińskiego ${ }^{40}$. We władzach drugiej organizacji - powstałego w 1930 r. Stowarzyszenia Żydowskich Artystów Plastyków w Polsce ${ }^{41}$ - odnajdujemy jedynie nazwisko Łucji Welczer-Szwajgerowej (?-?), i to w Komisji Rewizyjnej ${ }^{42}$. Niestety niewiele wiemy o ich działalności w tych oficjalnych gremiach.

\section{Miłośniczki sztuki i mecenaski}

Kobiety były jednak obecne w Żydowskim Towarzystwie Krzewienia Sztuk Pięknych (nasza wiedza na temat Stowarzyszenia Żydowskich Artystów Plastyków w Polsce wciąż jest zbyt mała, by móc opisać udział kobiet). Była to jednak obecność w tle, na drugim planie. Kobiety nie rządziły, nie decydowały, ale pomagały i „dopełniały” oficjalną pozycję swych mężów. $\mathrm{Z}$ jednej strony były to prowadzone jeszcze w XIX-wiecznym stylu działania Komitetu Pań, które nie ograniczały się do organizacji balów i wieczorów artystycznych ${ }^{43}$ czy kolportowania biletów, ale także do codziennej pracy

37 Jechiel Jeszaja Trunk, Pojln. Zichrojnes un bilder, Nju Jork 1944-1953, t. 5, s. 52-63.

${ }^{38}$ Hanna Kubaszewska, Urszula Makowska (uzup.), Natanson (Natansonowa) Bella (Bela), [w:] Stownik artystów polskich $i$ obcych w Polsce działających: malarze, rzeźbiarze, graficy, t. 6, red. Katarzyna Mikocka-Rachubowa, Małgorzata Biernacka, Warszawa 1998, s. 26; Malinowski, Malarstwo i rzeźba Żydów..., s. 267.

39 Salon Doroczny LXXXVII. Żydowskie Towarzystwo Krzewienia Sztuk Pięknych, [kat. wystawy], Warszawa [1938], s. [2].

${ }^{40}$ Była to wspólna wystawa Belli Natansonowej i Józefa Śliwniaka, Salon Czesława Garlińskiego, ul. Mazowiecka 8. Natansonowa pokazała 28 obrazów olejnych: pejzaży i martwych natur.

${ }^{41}$ Związek Artystów Plastyków Żydowskich w Polsce, „Nasz Przegląd” 8 (1930), nr 165, s. 8 .

42 „Nasz Przegląd” 16 (1939), nr 175, s. 12.

${ }^{43}$ W niedzielę 23 grudnia 1928 r. o godz. 5 odbyła się ,w salonach Przedstawicieli Handlowych, ul. Królewska 16, towarzyska Czarna Kawa dla zasilenia funduszów na własną siedzibę instytucji urządzona staraniem Zarządu i Komitetu Pań”. Lista honorowych gospodyń i gospodarzy: dr. [doktorowa] A. Chorążycka, dr. [doktorowa] B. Chorążycka, sen. [senatorowa] Dawidsohnowa, S. Eljowiczowa, Rega Englowa, Rena Herszaftowa, R. Je- 
na rzecz Towarzystwa. Ich wsparcie finansowe i zaangażowanie (do organizacji często należeli obydwoje małżonkowie) wytwarzały snobizm na rzecz sztuki, snobizm narodowy i towarzyski. Przykładem może być pokaz prac metaloplastycznych Marka Szwarca urządzony w mieszkaniu Zofii i Leona Feigenbaumów w kamienicy przy ul. Hożej 62 (14-15 maja 1927 r. $)^{44}$.

Charytatywne działania na rzecz społeczności żydowskiej były zarówno religijną powinnością, jak i koniecznością. Pomocy potrzebowały nie tylko instytucje artystyczne, ale i twórcy. Bela Kronstein, żona adwokata Feliksa Kronsteina ${ }^{45}$, w czasie I wojny światowej była studentką warszawskiej Szkoły Sztuk Pięknych. Chociaż (prawie) nie wystawiała ${ }^{46}$, można jednak przypuszczać, że wspierała męża nie tylko w jego zaangażowaniu w działalność ŻTKSP (w latach 1931-1936 był członkiem Zarządu), ale także w pomocy dla utalentowanego chłopaka z Kazimierza nad Wisłą, Chaima Goldberga, któremu Kronstein (razem z Henrykiem Kuną) wypłacał stypendium w wysokości 40 zł miesięcznie w czasie jego studiów w Akademii Sztuk Pięknych ${ }^{47}$.

Jedną z osób zaangażowanych na wielką skalę i w wielu dziedzinach w działalność filantropijną była Diana Eigerowa (1875-1945), członkini ŻTKSP ${ }^{48}$, kontynuatorka kolekcjonerskiej pasji swoich rodziców, Teresy i Markusa Silbersteinów. „Ta maleńka, misterna i bardzo żywa osoba była silną i ciekawą indywidualnością" - wspominała Hanna Mortkowicz-Olczakowa. - „Pani Diana ciągle pragnęła komuś pomagać, kogoś zapraszać

leniowa, I. Kirszenbergowa, inż. [inżynierowa] J. Leszczyńska, dr. [doktorowa] Lejpunerowa, dr. [doktorowa] Lewittowa, dr. [doktorowa] Miszurska, adw. [adwokatowa] B. Natansonowa, dr. [doktorowa] S. Neumanowa, Z. Orzechowa, dr. [doktorowa] Przygoda, E. Ryssowa, prof. [profesorowa] Schorowa; dr B[orys] Chorążycki, M[aksymilian] Eljowicz, A[dam] Herszaft, J[ózef] Hirszfeld, dr A. Neuman, M[aurycy] Orzech, dr Przygoda, radny St[anisław] Rozenberg, red. S[aul] Wagman, red. S[amuel] Wołkowicz. „Nasz Przegląd” 6 (1928), nr 352, s. 11.

${ }^{44}$ Album Artysty I, Archiwum Marka i Eugenii Szwarców, Muzeum Historii Żydów Polskich POLIN, nlb.

${ }^{45}$ Feliks Kronstein - zob. Lista adwokatów Okręgu Sądu Apelacyjnego w Warszawie (okrag Izby Adwokackiej Warszawskiej) na dzień 15 grudnia 1938 r., Warszawa 1938, s. 29. Wpisany na listę w 1918 r., ul. Królewska 23.

46 Jedyny raz pokazała swoją pracę Wnętrze na Wystawie Prac Artystów Żydowskich zob. Katalog Wystawy Prac Artystów Żyd...., poz. kat. 328.

47 Archiwum Akademii Sztuk Pięknych w Warszawie, Akta studentów sprzed 1939, nr 256.

${ }^{48}$ Potwierdza to losowanie dzieł sztuki dla członków ŻTKSP z 19 grudnia 1935 r., kiedy to „konsulowa Diana Eigerowa” (honorowym konsulem Danii był jej pierwszy mąż Bolesław Eiger) wylosowała pracę Ulica Icchoka V. Braunera. „Nasz Przegląd” 13 (1935), nr 360, s. 15. 
i żywić, komuś dawać zapomogi i podarunki, nawet wbrew jego woli”"49. Odziedziczone po przedwczesnej śmierci męża i syna aktywa przeznaczyła na rozmaite fundacje dobroczynne i stypendia.

Było wśród nich stypendium dla studentów-Żydów Akademii Sztuk Pięknych w Warszawie. W Księdze Protokołów Rady Gtównej tej uczelni pod datą 16 stycznia 1928 r. zapisano: „Przyjąć zapis p. Diany Eigerowej w sumie złotych w złocie $9000-8$ oblig. Banku Gospodarstwa Krajowego, jako fundusz stypendialny im. artysty-malarza Samuela Hirszenberga na warunkach wymienionych w liście p. Eigerowej z dnia 5 stycznia r.b." ${ }^{50}$. Stypendia były przyznawane do roku 1939 i dzięki nim wielu studentów Akademii Sztuk Pięknych (byli wśród nich tylko chłopcy) mogło wyruszyć w artystyczne podróże do Francji i Włoch ${ }^{51}$.

Diana Eigerowa również posiadała kolekcję sztuki. Nie wiemy niestety, jakie dzieła znajdowały się w jej zbiorach, śladem mogą być darowizny dla instytucji żydowskich oraz zakupy i wypożyczenia na wystawy ${ }^{52}$. Fakt donacji dla nowej instytucji artystycznej w Erec Israel świadczy o jej zaangażowaniu w życie żydowskie nie tylko w Polsce, ale i w przyszłym państwie żydowskim w Palestynie. W 1936 r. ofiarowała płaskorzeźbę Henryka Glicensteina Portret kobiety ${ }^{53}$ Muzeum Sztuki w Tel Awiwie ${ }^{54}$. W tym samym roku Głównej Bibliotece Judaistycznej przy Wielkiej Synagodze na Tłomackiem podarowała rzeźbę Prorok Glicensteina, obraz zatytułowany Chłopiec braci Seidenbeutlów oraz Statut Kaliski Artura Szyka ${ }^{55}$.

${ }^{49}$ Hanna Mortkowicz-Olczakowa, Bunt wspomnień, Warszawa 1961, s. 338.

${ }^{50}$ Księga Protokołów Rady Głównej Szkoły Sztuk Pięknych w Warszawie, Archiwum ASP w Warszawie.

${ }^{51}$ Renata Piątkowska, Studenci wyznania mojżeszowego w warszawskiej Akademii Sztuk Pięknych (1923-1939). Studia - debiuty - kariery, „Biuletyn Historii Sztuki” 77 (2015), nr 4, s. 688 .

${ }^{52}$ W kolekcji Eigerowej były nie tylko prace artystów-Żydów. Z jej korespondencji z Instytutem Propagandy Sztuki (IPS) wiemy, że w 1932 r. Eigerowa zakupiła rzeźbę Magdaleny Gross z wystawy w IPS. List z 22 marca 1932, Zbiory Specjalne Instytutu Sztuki PAN, Archiwum IPS, sygn. 70. W 1930 r. Diana Eiger otrzymała list z podziękowaniem za wypożyczenie na wystawę obrazu Tadeusza Pruszkowskiego Fragment, Zbiory Specjalne Instytutu Sztuki PAN, Archiwum IPS, sygn. 70.

${ }^{53}$ List Polsko-Palestyńskiej Izby Handlowej z 17 kwietnia 1936, Tel Aviv Museum of Art, The Museum Archive, sygn. 283, poz. 2. Henryk Glicenstein Portret kobiety, brąz, odlew, płaskorzeźba, $2824 \mathrm{~cm}$, sygn. w prawym dolnym rogu: H. GLICENSTEIN, Tel Aviv Museum of Art, inv. no. 991. Zob. Fragmented Mirror: Exhibition of Jewish Artists, Berlin 1907, red. Batsheva Goldman-Ida, [kat. wystawy], Tel Aviv Museum of Art, Tel Aviv 2009, s. 102.

${ }_{54}$ Muzeum otwarto w 1932 r. W Warszawie działało Towarzystwo Przyjaciół Muzeum w Tel Awiwie.

55 Sprawozdanie z budowy i opis gmachu 1928-1936, Komitet Budowy Gmachu Gtównej Biblioteki Judaistycznej przy Wielkiej Synagodze w Warszawie, Komisja Techniczna, Warszawa 1936, s. 36. 
Tę „towarzysko-dobroczynną” część działalności ŻTKSP uzupełniały Bale Sztuki Żydowskiej. W karnawale bawiła się cała Warszawa, bale organizowali żydowscy lekarze i akademicy, prawnicy, aktorzy i inżynierowie, dziennikarze i wiele innych środowisk. Były to wydarzenia, na których nie chodziło tylko o piękne toalety, „bukieciki i mufki”56, stylowy kostium czy „turniej póz malarskich" ${ }^{57}$ (podkreślenie w oryginale), nawet nie o rewię pajaców i karykatur znanych osobistości Warszawy ${ }^{58}$, lecz o zdobycie

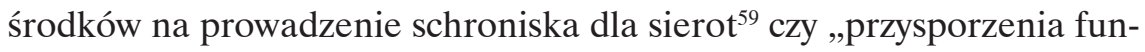
duszów żydowskiej wystawie sztuki” ${ }^{00}$. Dla wielu instytucji żydowskich, zwłaszcza charytatywnych czy kulturalnych, oznaczało to często być albo nie być, dotacje gminne (czy - rzadziej - miejskie) nie pokrywały bowiem kosztów ich działalności ${ }^{61}$ (il. 3). O patronat nad pierwszym Balem Sztuki Żydowskiej, który odbył się 25 lutego 1922 r., poproszono wybitnych twórców i reprezentantów żydowskiej inteligencji i świata kultury oraz ich małżonki ${ }^{62}$. Tę tradycję kontynuowano, a Gospodyniami i Gospodarzami Balów były znakomitości życia społecznego, kulturalnego i politycznego stolicy (il. 4). Te same nazwiska znajdujemy w kolejnych relacjach, można więc przypuszczać, że chodziło nie tylko o udział w towarzyskiej fecie, lecz o trwałe wsparcie działalności Towarzystwa ${ }^{63}$. Takie były przyjemności (i obowiązki) miłośników sztuki. Natomiast artyści pracowali

56 „Ewa” 5 (1932), nr 15, s. 6.

${ }^{57}$ W 1927 r. na Balu Sztuki Żydowskiej jedną z atrakcji był turniej póz malarskich, zorganizowany pod hasłem: „Te, które pragniemy malować”. Namalowane wówczas (?) portrety miały być pokazane na wystawach ŻTKSP. Między uczestniczkami rozlosowano sto bezpłatnych biletów rocznych na wystawy ŻTKSP. Być może także w innych latach zachęcano w ten sposób do zwiedzania wystaw. „Nasz Przegląd” 5 (1927), nr 76, s. 10.

58 „Nasz Przegląd” 8 (1930), nr 131, s. 16.

59 Wielki Bal Maskowy Schroniska dla Sierot przy ul. Twardej 6 w sobotę 4 lutego 1927 roku, w sali teatru „Nowości”, „Nasz Przegląd” 5 (1927), nr 33, s. 1.

60 „Nasz Kurier” 3 (1922), nr 47, s. 3.

${ }^{61} \mathrm{O}$ balach organizowanych przez Związek Literatów i Dziennikarzy Żydowskich pisał Melech Rawicz: „Wiele instytucji żydowskich w Warszawie organizowało bale w celach zarobkowych. Również Związek Literatów latami pokrywał swój deficyt tym, co zarobił na ich organizacji. [Jednak] bale, które on organizował, były najhuczniejsze, najlepiej zorganizowane i najliczniej odwiedzane. Każdy z nich zapowiadano jako »bal nad balami«. Tymczasem [w czasie ich trwania] nie sposób było upilnować porządku, nawet przy pomocy policji. Nie udawało się również zrealizować przewidzianego programu. Literaci bywali na tych balach coraz rzadziej i rzadziej, aż w końcu zupełnie ich zaniechano". Melech Rawicz, Tłomackie 13 (Farejn fun Jidisze Literatn un Żurnalistn in Warsze), [w:] tenże, Dos majse buch fun majn lebn. Jorn in Warsze 1921-1934, thum. Magdalena Ruta, Tel Aviv 1975, s. 333.

${ }_{62}$ Nie podano jednak ich nazwisk, „Nasz Kurier” 3 (1922), nr 47, s. 3.

${ }^{63}$ Zob. m.in.: „Nasz Przegląd” 10 (1932), nr 91, s. 9; „Nasz Przegląd Ilustrowany” 9 (1932), nr 15, s. 5. 


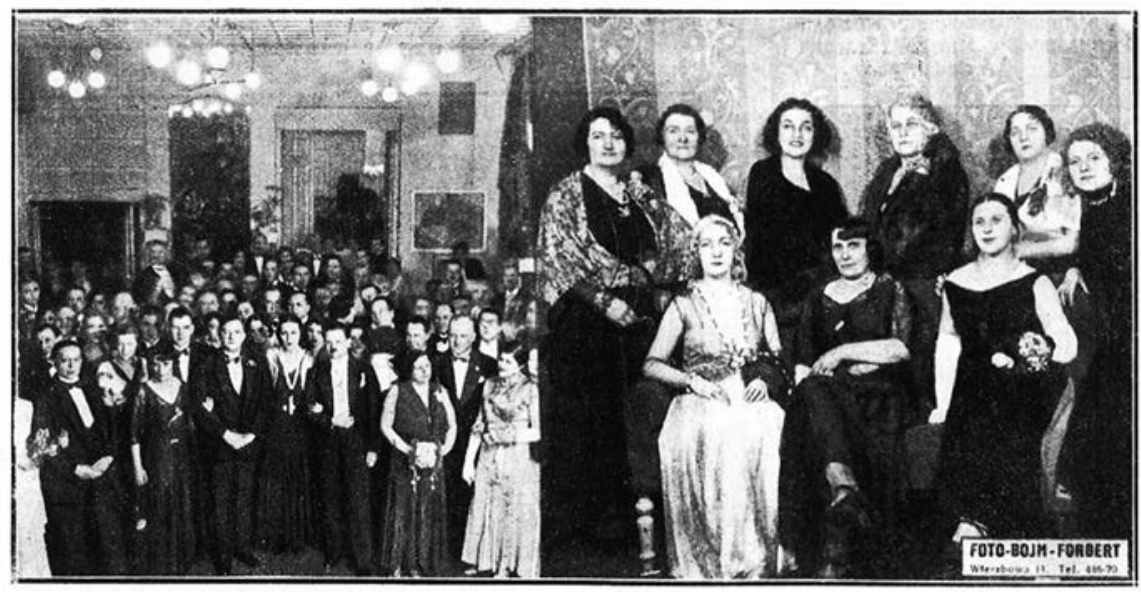

Il. 3. Wiosenny Bal Sztuki Żydowskiej w „Bristolu”. Grupa Komitetu Pań - siedzą (od lewej): Tea Arciszewska, prezesowa Mayzlowa, Pave; stoją (od lewej): [Paulina] Woldenbergowa, [Paulina] Mamutowa, mec. [mecenasowa] [B.] Natansonowa, Płońska, [Zinaida] Jackowska, dyr. [dyrektorowa] Finkelsteinowa, „Nasz Przegląd Ilustrowany” 8 (1932), nr 15, s. 5.

„nad stylowemi dekoracjami, które przeistoczą salę balową w istny pałac czarodziejski”"64.

Bale były wydarzeniami elitarnymi, łatwo je więc lekceważyć i spychać do kącika towarzyskiego. Dostarczały nie tylko rozrywki. Tworzyły środowisko, pozwalały zebrać fundusze na najważniejsze zadania Towarzystwa organizację wystaw i popularyzację sztuki. O wystawach artystek piszę dalej, teraz chciałabym zwrócić uwagę na publiczność, można bowiem przypuszczać, że kobiety stanowiły znaczącą jej część (choć trzeba też uczciwe przyznać, że nie mamy właściwie żadnych pewnych danych na ten temat). Kim więc była publiczność żydowska, której tak poszukiwano, o którą tak zabiegano?

Dla rozwoju i umocnienia żydowskiego życia artystycznego w stolicy podstawowe znaczenie miała prasa. Bez „Naszego Przeglądu” ${ }^{2}$, poczyt-

${ }^{64}$ Zob. m.in.: „Nasz Przegląd” 2 (1924), nr 39, s. 4; 2 (1924), nr 356, s. 5; 5 (1927), nr 82, s. 11; „Ewa” 3 (1930), nr 20, s. 6.

${ }^{65} \mathrm{O}$ „Naszym Przeglądzie” zob. Janina Katarzyna Rogozik, „Nasz Przegląd”: między „hajntyzmem” a „mechesyzmem”, „Zeszyty Prasoznawcze” 40 (1997), nr 1-2, s. 123-138; 40 (1997), nr 3-4, s. 124-139; Steffen, Jüdische Polonität...; taż, „Polska - to także my!”. Prasa polsko-żydowska (1918-1939), [w:] Studia z dziejów trójjęzycznej prasy żydowskiej na ziemiach polskich (XIX-XX w.), red. Joanna Nalewajko-Kulikov, Warszawa 2012, s. 129-146. 


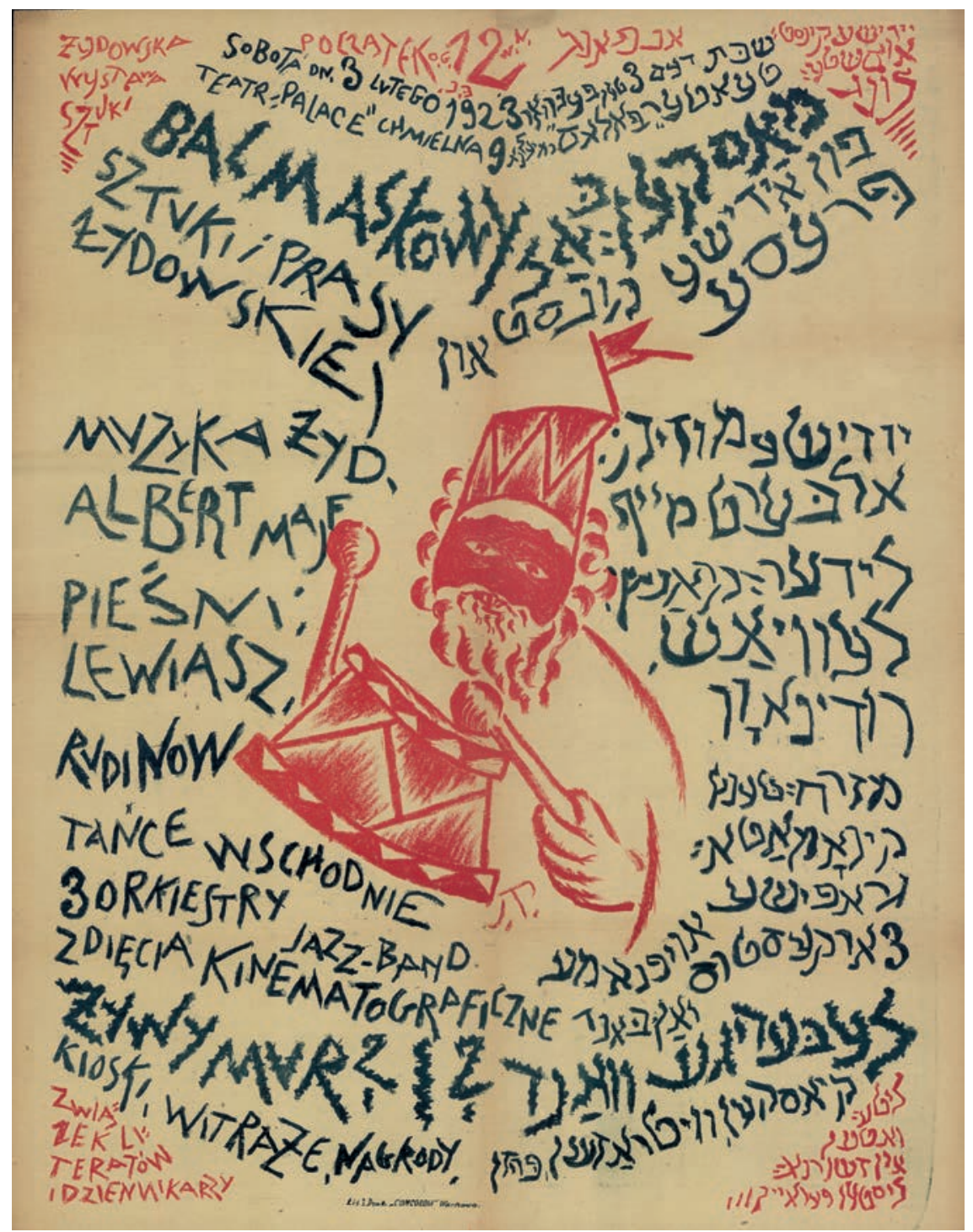

Il. 4. Afisz obwieszczający Bal maskowy sztuki i prasy żydowskiej Związu Żydowskich Literatów i Dziennikarzy i Żydowskiej Wystawy Sztuki, sobota, 3 lutego 1923, Teatr „Palace”, Chmielna, projekt Izrael Tykociński, Biblioteka Narodowa, sygn. DŻS IK 2 f. 
nego polsko-żydowskiego dziennika, trudno sobie wyobrazić przetrwanie i rozwój Żydowskiego Towarzystwa Krzewienia Sztuk Pięknych. „Nasz Przegląd” - podobnie jak warszawski tygodnik dla kobiet „Ewa” - czytany był głównie przez spolonizowaną inteligencję, często nieznającą już jidysz i hebrajskiego, dla której jednak żydowska sprawa narodowa wyznaczała najbliższe kręgi tożsamości ${ }^{66}$. Do tego grona zaliczało się także wielu członków ŻTKSP ${ }^{67}$.

Obydwa czasopisma wiele uwagi poświęcały życiu artystycznemu stolicy, regularnie publikowane były tam recenzje z wystaw w Zachęcie, Instytucie Propagandy Sztuki czy w prywatnych galeriach oraz sprawozdania z ekspozycji paryskich. Czytelnikom prezentowano pełne spektrum życia artystycznego. Niewątpliwie jednak „Nasz Przegląd” był przede wszystkim główną trybuną i rzecznikiem ŻTKSP, na jego łamach bowiem nie tylko pisano o artystach i wystawach ${ }^{68}$, ale także reklamowano towarzyszące pokazom spotkania literackie, odczyty, akademie i koncerty, zapraszano na doroczne Bale Sztuki Żydowskiej, wieczornice klubowe i „Czarne kawy”, poranki taneczne i dancingi. W ilustrowanym dodatku regularnie zamieszczano reprodukcje prac artystów-Żydów, często rezerwując dla nich strony tytułowe i całe kolumny ${ }^{69}$, równie częste były zdjęcia z wernisaży i bankietów ${ }^{70}$. Ilość informacji poświęconych wystawom i artystom, obfitość reprodukcji zamieszczanych na łamach „Naszego Przeglądu Ilustrowanego”

${ }^{66}$ Steffen, Jüdische Polonität...; Landau-Czajka, Polska to nie oni...

${ }^{67}$ Warto zauważyć, że wśród osób zaangażowanych w żydowskie życie artystyczne prawie nie spotykamy nazwisk z kręgu warszawskich integracjonistów, przedstawicieli wielkich rodzin z grona Polaków wyznania mojżeszowego, które w XIX w. patronowały pierwszym artystom-Żydom w Warszawie. Ostatnim miejscem, w którym trwała ich obecność, było Muzeum Starożytności Żydowskich im. Mathiasa Bersohna. W opublikowanym w 1939 r. wykazie eksponatów nabytych lub podarowanych muzeum znajdujemy wśród darczyńców m.in. nazwiska Zuzanny Rabskiej (córki fundatora) i Cecylii Oderfeldowej, zob. Rafał Gerber, Muzeum im. Mathiasa Bersohna przy Wyzn. Gminie Żydowskiej w Warszawie, Warszawa 1939, s. 66-70.

${ }^{68} \mathrm{Na}$ łamach „Naszego Kuriera” i „Naszego Przeglądu” krytyką artystyczną zajmowali się: Jerzy Centnerszwer, Leopold Strakun, Michał Weinzieher. O wystawach, artystach, zabytkach i sztuce pisywali także Tea Arciszewska, Paulina Apenszlak, Eli Baruchin, Henryk Berlewi, Maksymilian Feurring, Ber (Boas) Karlinius, Szlomo Reiss, Leon Dreikurs, Marek Szwarc, Majer Bałaban, Otto Schneid, Henryk Majzner, Edward Kleinerer, Mikołaj Wadyas, Andrzej Marek. Brakuje wciąż analizy krytyki sztuki na łamach „Naszego Przeglądu”.

${ }^{69}$ „Nasz Przegląd Ilustrowany” 6 (1928), nr 24, s. 1. „Salon Zimowy” w Żyd. Tow. Krzewienia Sztuk Pięknych, „Nasz Przegląd Ilustrowany” 8 (1930), nr 2, s. 3.

${ }^{70}$ Np. Jubileusz Maurycego Trębacza. Bankiet w Żydowskim Towarzystwie Krzewienia Sztuk Pięknych, „Nasz Przegląd Ilustrowany” 9 (1931), nr 21, s. 5. Uroczyste otwarcie wystawy jubileuszowej prac Maurycego Trębacza, „Nasz Przegląd Ilustrowany” 9 (1931), nr 15, s. 6. 
budowały przekaz potwierdzający rolę i znaczenie sztuk pięknych w nowoczesnym społeczeństwie żydowskim ${ }^{71}$.

Sztuki piękne były też stale obecne w tygodniku dla kobiet „Ewa” wydawanym przez Izę Wagmanową (?-?) i redaktorkę naczelną Paulinę Apenszlak (1900-1976) ${ }^{72}$, zob. il. 5. „Ewa”, mimo krótszego niż „Nasz Przegląd" okresu działalności (1928-1933), nie tylko nie ustępowała dziennikowi w popularyzacji sztuk pięknych (o wystawach pisywali tam Paulina Apenszlak $^{73}$ i Michał Weinzieher, stały recenzent „Naszego Przeglądu”), ale w dużo szerszym zakresie prezentowała oryginalną twórczość artystek zarówno tych działających w Polsce ${ }^{74}$, jak i za granicą, przede wszystkim w Paryżu, gdzie współpracowniczką „Ewy” była Eugenia Markowa (1895-1973) ${ }^{75}$. Starania grona redakcyjnego - do którego należała m.in. wspomniana wyżej Zofia Feigenbaum ${ }^{76}$ - by zmienić obraz kobiety żydowskiej z tej, którą „pragniemy malować”77, w tę, dla której najważniejsza jest jej niezależna i oryginalna twórczość, ocenić należy jako udane ${ }^{78}$.

Kiedy w 1921 r. inicjowano Żydowską Wystawę Sztuki, argumentowano, że chodzi przede wszystkim o kontakt „ze swojem społeczeństwem, które w niedostatecznej wprawdzie mierze - lecz bądź co bądź jest jedynym

71 Także w dodatkach ilustrowanych do lwowskiej „Chwili” czy warszawskiego „Nowego Głosu" zamieszczano reprodukcje dzieł sztuki.

72 Nazwiska wydawczyń wskazują na rodzinne związki z „Naszym Przeglądem”: Iza Wagmanowa była żoną Saula Wagmana, a Paulina Apenszlak - Jakuba Apenszlaka.

${ }^{73}$ P. A. [Paulina Apenszlak], Pędzlem i farbą..., „Ewa” 2 (1929), nr 21, s. 8; taż, Triumf sztuki kobiecej. Wystawa pejzaży włoskich Centnerszwerowej, „Ewa” 2 (1929), nr 48, s. 1. Apenszlakowa pisywała też recenzje do „Naszego Przeglądu”: P. J. A. [Paulina Jamajka Apenszlak], Żydowska Wystawa Sztuki, „Nasz Przegląd” 1 (1923), nr 185, s. 3; P[aulina] Apenszlakowa, Salon zimowy w Żyd. Tow. Krzewienia Sztuk Pięknych, „Nasz Przegląd” 8 (1930), nr 17, s. 6; P. A. [Paulina Apenszlak], Wystawa obrazów St. Centnerszwerowej, Natana i Ireny Reingewirców, „Nasz Przegląd” 8 (1930), nr 345, s. 4.

${ }^{74}$ W pracowni artystki malarki. „Ewa” u p. Stanistawy Centnerszwerowej, „Ewa” 1 (1928), nr 7, s. 3; Malarka Ghetta. „Ewa” u p. R. Mundlakówny - znanej malarki żydowskiej, „Ewa” 1 (1928), nr 37, s. 3.

${ }^{75}$ Gina Szwarc (żona Marka Szwarca), pod koniec lat dwudziestych pisząca pod pseudonimem Eugenia Markowa, rozpoczęła współpracę z czasopismami w Polsce, m.in. z „Ewą” i „Kobietą Współczesną”. Eugenia Markowa, Godzina u Chany Orloff, „Ewa” 1 (1928), nr 11, s. 1; taż, Godzina u Meli Muter, „Ewa” 1 (1928), nr 16, s. 2; taż, Godzina u Olgi Boznańskiej, „Ewa” 1 (1928), nr 19, s. 2.

${ }_{76}$ Monika Szabłowska-Zaremba, Dziennikarki międzywojennej prasy polsko-żydowskiej (wstępne rozpoznanie), „Archiwum Emigracji” 17 (2014), z. 1-2, s. 41.

77 „Nasz Przegląd” 5 (1927), nr 76, s. 10.

${ }^{78} \mathrm{O}$ „Ewie" zob. m.in.: Eva Plach, Feminism and Nationalism on the Pages of "Ewa: Tygodnik” 1928-1933, „Polin” 18 (2005), s. 241-262; Monika Szabłowska-Zaremba, Portret syjonistki z łam „Ewy”, tygodnika dla pań (1928-1933), [w:] Żydzi wschodniej Polski, seria 3: Kobieta żydowska, red. Anna Janicka, Jarosław Ławski, Barbara Olech, Białystok 2015, s. 545-560. 


\section{f. BerlewL. Portret p. Pauliny A.}

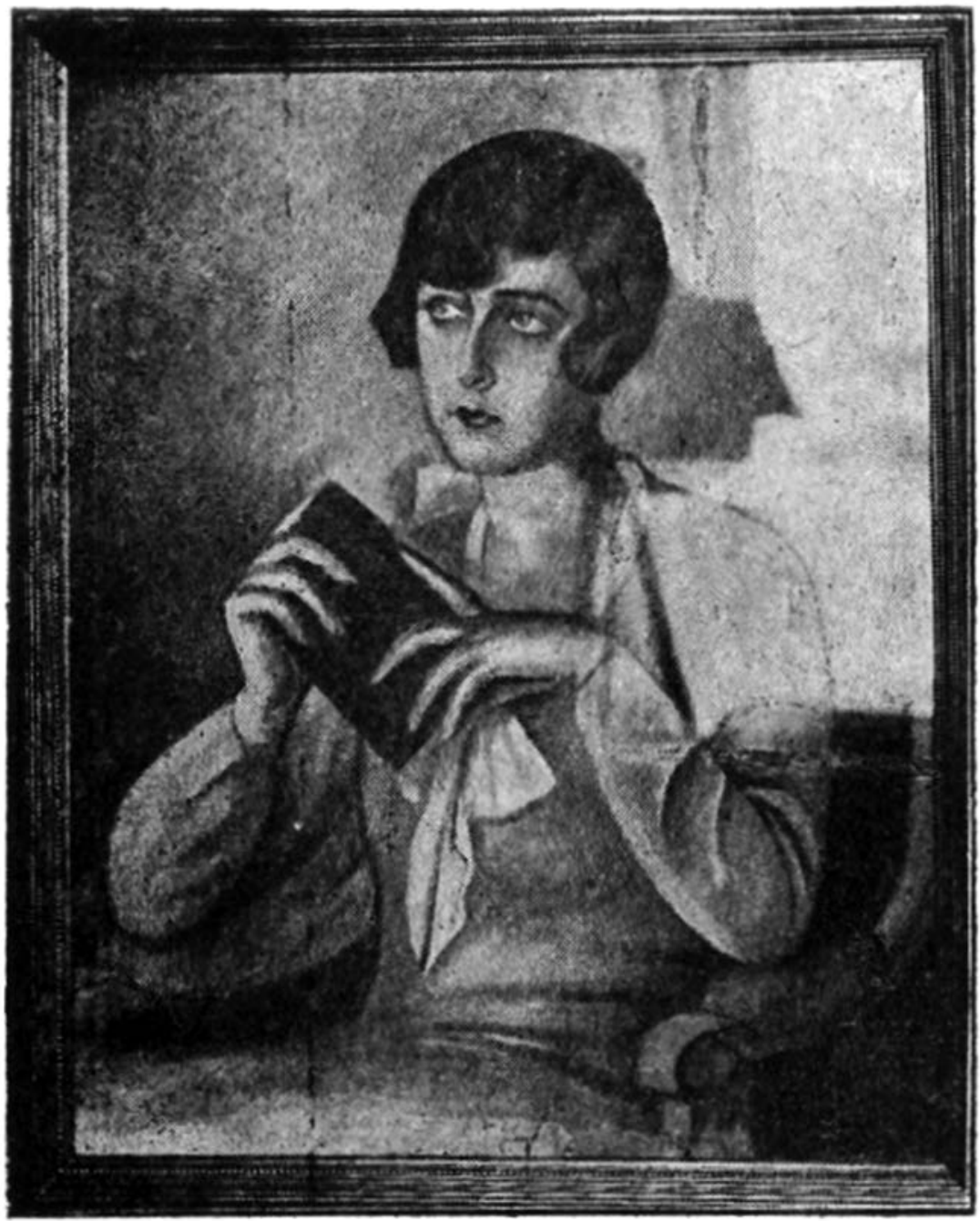

Il. 5. Henryk Berlewi, Portret Pauliny Apenszlak, „Nasz Przegląd Ilustrowany” 3 (1927), nr 48, s. 5. 
tych artystów mecenasem, odbiorcą i podporą"79. Ta społeczność wciąż w przeważającej masie mówiła po żydowsku. Czy udało się więc zainteresować sztuką żydowską ulicę? Czy przekonano trwającą przy tradycji religijnej część wspólnoty i tę, dla której jidysz - mame-loszn Żydów w Europie Środkowo-Wschodniej - był treścią życia, językiem kultury i dnia codziennego? To dla nich zaproszenia, katalogi, plakaty (podobnie jak nazwa i godło Towarzystwa) były dwujęzyczne, ogłoszenia o wystawach i wydarzeniach zamieszczano w jidyszowych dziennikach, podkreślano bliskie związki z jidyszowym teatrem i literaturą.

Wiemy, że salony wystawowe licznie odwiedzała jidyszowa inteligencja - aktorzy, pisarze, dziennikarze (np. Nojech Pryłucki ${ }^{80}$ relacjonował na łamach „Der Moment” wystawy Towarzystwa), naukowcy oraz nauczyciele i działacze. Jednak łamy prasy jidyszowej („Literarisze Bleter”11 i dzienników: „Der Moment”, „Hajnt” i bundowskiej „Folkscajtung”), mimo iż otwarte dla sztuk pięknych, poświęcały im zdecydowanie mniej uwagi, wyjątek czyniąc dla sztuki żydowskiej i twórczości artystów-Żydów.

Podsumowując część poświęconą miłośniczkom (i miłośnikom) sztuki, trudno uniknąć gorzkiej refleksji. Kiedy przegląda się listy członków rozmaitych stowarzyszeń i instytucji żydowskich w międzywojennej Warszawie, uderzające jest, jak wiele nazwisk się powtarza w tych gremiach, jak niewielka była grupa ludzi aktywnie włączających się w działalność organizacji charytatywnych i kulturalnych. Możemy też przypuszczać, że właśnie ta grupa, często już spolonizowana, mieszczańska, inteligencka, której znaczącą część stanowiły kobiety, dominowała wśród publiczności na wystawach. Przewrotne potwierdzenie tego faktu znajdujemy w mało pochlebnym, wręcz złośliwym reportażu jidyszowego pisarza (i zarazem malarza) Efraima Kaganowskiego:

Niech już będzie w obcym mieszkaniu, byle by tylko wystawa się odbyła, bo malarstwo to rzeczywiście rzecz godna szacunku. A ponieważ jest to rzecz szlachetna, znajduje się w rękach szlachetnych ludzi, którzy na tak zwanych „wernisażach”, czyli premierach, mówią po polsku, takich, których nie spotka się w innych publicznych miejscach żydowskich. Porządni mężczyźni i porządne damy. Kłaniają się,

79 Apenszlak, Z powodu rocznicy..., s. 4.

${ }^{80}$ O Pryłuckim zob. Keith (Kalman) Weiser, Jewish People, Yiddish Nation: Noah Prylucki and the Folkists in Poland, Toronto 2011.

${ }^{81} \mathrm{Na}$ jego łamach o sztuce pisali m.in.: Chana Kowalska, Natan Korzeń, Alter Kacyzne, Feliks Frydman, Otto Schneid, Józef Sandel. Zob. też Aleksandra Geller, „Literarisze Bleter” (1924-1939), [w:] Studia z dziejów trójjęzycznej prasy żydowskiej..., s. 101-112. 
pochylają, całują ręce. Przychodzą uznani działacze społeczni, literaci, dziennikarze, przybywają lekarze, adwokaci, inżynierowie, choć częściej doktorowe, inżynierowe i mecenasowe. Pokazuje się trochę karakułów, fok, brajtszwanców. I kilku naszych malarzy ma możliwość przekonania się, że nie są aż tak ubodzy, jak się im wydaje. Widzą, że naród dba o nich i o nich pamięta ${ }^{82}$.

\section{Wokół wystaw - artystki}

\section{„Pragnę w każdym razie być sobą..." 83}

W tradycyjnej kulturze żydowskiej dostęp kobiet do życia religijnego był ograniczony, a ich rola sprowadzona do bycia matką i żoną ${ }^{84}$. W XIX w. sfera sztuki, teatru i muzyki stała się dla kobiet sposobem wyjścia poza te tradycyjne role. Jednak ta droga dostępna była niewielu. Dopiero narastające pod koniec stulecia tendencje modernizacyjne pozwoliły coraz większej liczbie Żydówek podejmować studia artystyczne. W Warszawie na początku XX w. wciąż było ich mało. Mela Muter (1876-1967), by dalej się kształcić, musiała wyjechać do Paryża ${ }^{85}$, a swą jedyną wystawę w stolicy pokazała w 1923 r. w Zachęcie. Stanisława Centnerszwerowa i Sara Lipska mogły się już uczyć w otwartej w 1904 r. Szkole Sztuk Pięknych (od 1932 r. - Akademii Sztuk Pięknych), nowoczesnej, bez bagażu tradycyjnych hierarchii zarówno w kwestiach programowych, jak i dostępu do niej kobiet. W dwudziestoleciu międzywojennym coraz więcej kobiet nie tylko studiowało na uczelniach artystycznych, lecz także z sukcesami kontynuowało karierę.

Kiedy analizujemy udział kobiet w wystawach Żydowskiego Towarzystwa Krzewienia Sztuk Pięknych, okazuje się, że chociaż w dorocznych salonach były one szeroko reprezentowane, to tylko siedem artystek miało możliwość przedstawienia swej twórczości na ekspozycjach indywidualnych. Cztery spośród nich opromieniała sława Paryża; były to: Alicja

${ }^{82}$ Efraim Kaganowski, Ojf der jidiszer kunst-ojssztelung (a reportaż), „Hajnt” 24 (1936), nr 297, s. 6 (tłum. cytatu Anna Szyba). Równie złośliwy portret miłośniczki sztuki znajdujemy w opowiadaniu Isaaca Bashevisa Singera - zob. Isaac Bashevis Singer, Przyjaciel domu, [w:] tenże, Śmierć Matuzalema i inne opowiadania, tłum. Maria Olejniczak-Skarsgård, Warszawa 2006, s. 22-23.

${ }^{83}$ U Stanistawy Centnerszwerowej. Wizyta „Naszego Przegladu” u znakomitej malarki, „Nasz Przegląd” 6 (1929), nr 321, s. 6.

${ }^{84}$ Bożena Umińska, Postać z cieniem. Portrety Żydówek w polskiej literaturze od końca XIX wieku do 1939 roku, Warszawa 2001, s. 53-54.

${ }^{85}$ Przed wyjazdem uczyła się w Szkole Rysunku i Malarstwa dla Kobiet Miłosza Kotarbińskiego. 
Hohermann, Zofia Bornstein, Pola Lindenfeld i Estera Karp. Jedna - Irena Rajngewirc - wystawiała wspólnie z mężem Natanem. Dwie - Regina Mundlak (1887-1942) ${ }^{86}$ i Stanisława Centnerszwerowa (1889-1943) ${ }^{87}$ karierę rozpoczęly jeszcze przed Wielką Wojną ${ }^{88}$. W tym samym czasie ponad osiemdziesięciu artystów zaprezentowało swą twórczość na indywidualnych wystawach w ŻTKSP, choć trzeba pamiętać, że wiele z tych ekspozycji było wspólnymi pokazami dwóch lub trzech twórców.

Centnerszwerowa była najważniejszą żydowską artystką z pokolenia, które rozpoczęło karierę jeszcze przed Wielką Wojną. Malarka konsekwentnie, mimo zaangażowania w życie żydowskie, starała się nie zamykać swej sztuki w żadnej narodowej wizji. Jej dwie wystawy indywidualne w Żydowskim Towarzystwie Krzewienia Sztuk Pięknych (1929/30, 1930/31), podobnie jak wcześniejsze w Salonie Czesława Garlińskiego (1924, 1927, 1929), prezentowały artystkę nowoczesną, odwołującą się do sztuki awangardowej (w jej formistycznym wydaniu) i do sztuki dawnej - prowadziła dialog (nowoczesny) z przeszłością. Po wystawie widoków z Wenecji Michał Weinzieher pisał: „Kilkadziesiąt obrazów malarki stanowi poważny plon artystyczny imponujący kulturą i dojrzałością, świadczący zarazem, że stara Italia tylekroć malowana, widziana przez pryzmat szczerego talentu, może być przedmiotem nowoczesnego dzieła sztuki”"9. Mówiąc o swoim malarstwie, Centnerszwerowa zdecydowanie stwierdzała:

Pragnę w każdym razie być sobą... Nie liczę się zbytnio z tem, co jest uświęcone kanonem. [...] Jestem zupełnie samotna, jeżeli idzie o mój stosunek do jakiejś zdeklarowanej odrębnej grupy artystycznej. [...] Czuję się lepiej w mojej samotności, nie mam potrzeby zastosowywania się do czyichś wymagań i upodobań ${ }^{90}$.

W salonach ŻTKSP królowały artystki mieszkające na stałe w stolicy Francji. Wszystkie reprezentowały siebie i swą sztukę w kategoriach nowoczesności (choć nie awangardy), dalekiej od żydowskiej sztuki narodowej, a ich twórczość zaliczana jest obecnie do międzynarodowego kręgu sztuki

${ }^{86}$ Anna Wierzbicka, Regina Mundlak, [w:] Stownik artystów polskich..., t. 5, red. Janusz Derwojed, Warszawa 1993, s. 669-670; Malinowski, Malarstwo i rzeźba Żydów..., s. 131-132.

87 Józef Sandel, Stanisława Centnerszwerowa, [w:] Stownik artystów polskich..., t. 1, red. Jolanta Maurin-Białostocka i in., Warszawa 1971, s. 298-299; Malinowski, Malarstwo i rzeźba Żydów..., s. 230-232.

${ }_{88}$ Renata Piątkowska, „Na palecie kobiecej”. Stanistawa Centnerszwerowa i Regina Mundlak - dwie perspektywy twórcze, [w:] Nieme dusze? Kobiety w kulturze jidysz, red. Joanna Lisek, Wrocław 2010, s. 283-297.

${ }^{89}$ Michał Weinzieher, Wystawa prac Stanistawy Centnerszwerowej, „Nasz Przegląd” 6 (1929), nr 329, s. 7.

${ }^{90}$ U Stanistawy Centnerszwerowej..., s. 6. 
École de Paris. Każda z nich znalazła w Paryżu własny język twórczości plastycznej, każda doczekała się (umiarkowanych) sukcesów na paryskim gruncie. O ich warszawskich wystawach sporo pisano, zwłaszcza o Hohermann i Bornstein.

Na pierwszej indywidualnej wystawie Alicji Hohermann (1902-1943) znalazły się prace, które przyniosły jej uznanie w Paryżu, gdzie mieszkała od roku 192191, zob. il. 6. Oprócz Kompozycji mechanofakturowych inspirowanych ideami Henryka Berlewiego (chociaż on sam uznał to za nieporozumienie ${ }^{92}$ ) były to portrety i martwe natury, w których awangardowe inspiracje malarka łączyła $\mathrm{z}$ dekoracyjnie traktowaną linią i barwną plamą. Ekspozycja ukazała najnowsze (i najmodniejsze) trendy paryskie, ale równie ciekawy był program odczytów i spotkań, a Hohermann z pasją włączyła się w propagowanie wystawy. W czasie dziesięciu tygodni jej trwania artystka kilkakrotnie spotkała się z widzami podczas bezpośredniej rozmowy lub prelekcji. W jednym $\mathrm{z}$ anonsów czytamy:

Dyskusja ta polegać będzie na tem, że każda osoba z publiczności będzie mogła zadawać pytania pani Hohermann, która ze swej strony będzie udzielała bardzo szczegółowych odpowiedzi.

Wymieniony sposób zaznajomienia się publiczności z dziełami sztuki jest zupełnie oryginalny i dotychczas nie praktykowany. Specjalnie ciekawe będzie, w jaki sposób ujmuje swe prace sama artystka ${ }^{93}$.

Prace Zofii Bornstein ${ }^{94}$ (1903-1990) prezentowane w ŻTKSP jesienią 1927 r. (il. 7) oraz na wystawie w 1934 r. znamy jedynie z nielicznych reprodukcji w prasie. Bornstein, w Paryżu używająca imienia Sonia, na wystawach pokazała przede wszystkim miejskie pejzaże, portrety i martwe natury ${ }^{95}$. „Dorobek Zofii Bornstein jest radosnem poszukiwaniem, świeżym oddechem Paryża i jego wiecznie młodej sztuki" ${ }^{96}$ - pisano, sama zaś ekspozycja przyjęta została z uznaniem: „Całość zapowiada mocny i śmiały

${ }^{91}$ XVII Wystawa Prac Dekoracyjnych Alicji Hohermann. Październik 1925 Listopad, Żydowskie Towarzystwo Krzewienia Sztuk Pięknych, Warszawa [1925]; Jerzy Malinowski, Barbara Brus-Malinowska, $W$ kręgu École de Paris. Malarze żydowscy z Polski, Warszawa 2007, s. $172-173$.

${ }^{92}$ Henryk Berlewi, Żyd. T-wo Krzewienia Sztuk Pięknych. Wystawa XVII. Prace dekoracyjne Alicji Hohermann, „Nasz Przegląd” 3 (1925), nr 289, s. 7.

93 „Nasz Przegląd” 3 (1925), nr 293, s. 9. Dyskusja odbyła się w niedzielę 25 października $1925 \mathrm{r}$.

${ }^{94}$ Po wojnie artystka przyjęła nazwisko Suzanne Berthet.

${ }_{95}$ Malinowski, Brus-Malinowska, W kręgu École de Paris..., s. 173.

${ }^{6}$ Jerzy Centnerszwer, Zofia Bornstein. Żyd. Tow. Krzew. Sztuk Pięknych, „Nasz Przegląd" 4 (1927), nr 330, s. 5. 


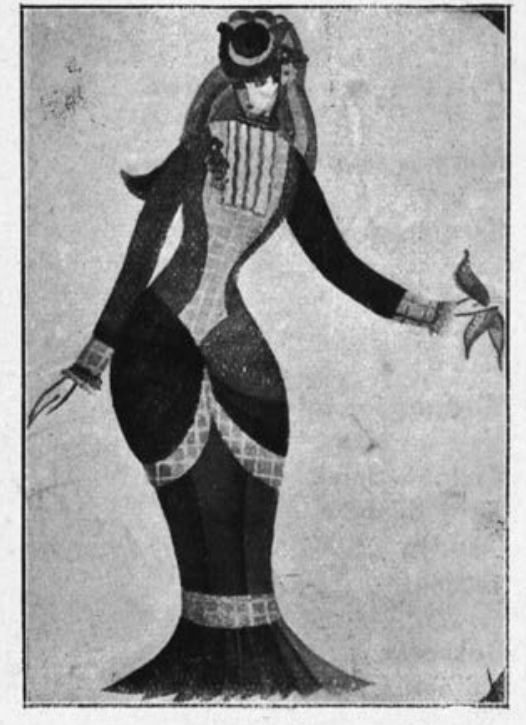

Dama z 1880 roku

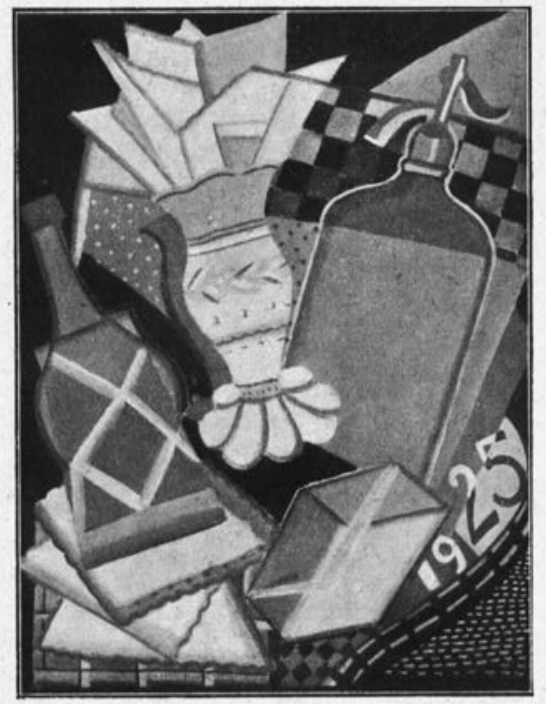

Martwa Natura.

Il. 6. Strony z katalogu XVII Wystawy Prac Dekoracyjnych Alicji Hohermann. Październik 1925 Listopad, Żydowskie Towarzystwo Krzewienia Sztuk Pięknych, Warszawa [1925].

talent. Wyczuwa się powiew silnej woli i świeżość temperamentu artystycznego, który tworzy z radością, zapałem i miłością do sztuki” - kończył swą entuzjastyczną w tonie recenzję Jerzy Centnerszwer ${ }^{97}$. Feliks Frydman dodawał: „Wystawa wywiera bardzo dobre wrażenie, jest poważnym osiągnięciem. [...] wniosła świeżość, w przestarzałą szablonową warszawską sztukę"98. Własną wystawę udało się zresztą artystce przedstawić warszawskiej publiczności wcześniej niż paryskiej, gdzie dopiero pod koniec 1928 r. miała pokaz w galerii „Mots et Images”99. Również następna warszawska wystawa Bornstein spodobała się krytykom. Konrad Winkler pisał: „artystka w swej ideowej przynależności do »École de Paris« posiada wiele szlachetnych akcentów, zwłaszcza w gamie tonów szarych, doskonale

97 Tamże.

98 Feliks Frydman, Di bilder ojssztelung fun Zofia Bornsztajn, „Literarisze Bleter” 4 (1927), nr 52, s. 1034 (tłum. cytatu - Anna Szyba).

99 Anna Wierzbicka, Świadectwa obecności. Polskie życie artystyczne we Francji w latach 1900-1939. Diariusz wydarzeń z wyborem tekstów, cz. 2: Lata 1922-1929, wybór, oprac. i wprowadzenie Anna Wierzbicka, Warszawa 2015, s. 470. 


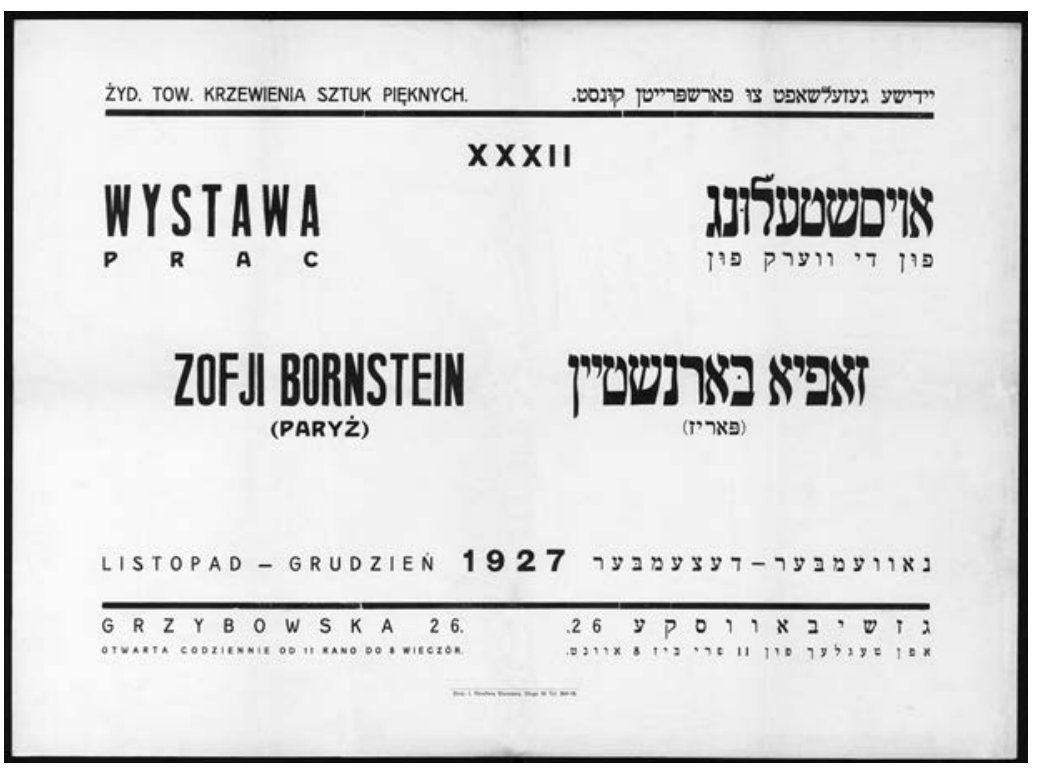

Il. 7. Afisz wystawy Zofii Bornstein w Żydowskim Towarzystwie Krzewienia Sztuk Pięknych, Warszawa [1927], Biblioteka Narodowa, sygn. DŻS IK 2f.

zharmonizowanych, oraz duże wyczucie malarskiego materiału. Wystawa godna zwiedzenia"100.

W połowie lat dwudziestych obydwie artystki jako pierwsze wprowadzały na salony Towarzystwa najnowszą sztukę paryską w jej oryginalnym, „kobiecym” - jak często określano zwłaszcza twórczość Hohermann wydaniu. To deprecjonujące sztukę kobiet określenie przywoływano nieraz, nie tylko zresztą w Warszawie, ale także w Paryżu. Nie ulega jednak wątpliwości, że oprócz wystawy Estery Karp (w 1933 r.) oraz Zygmunta Menkesa i Alfreda Aberdama były to najważniejsze w ŻTKSP pokazy współczesnej sztuki kręgu École de Paris.

Wystawy sztuki stosowanej w ŻTKSP zdominował małżeński duet Ireny i Natana Rajngewirców - orędowników modernizmu, minimalizmu i prostoty oraz śmiałego użycia czystego koloru ${ }^{101}$. Na wystawach w 1926 r. ${ }^{102}$

${ }^{100}$ K. W. [Konrad Winkler], Z wystaw warszawskich, „Polska Zbrojna” 13 (1934), nr 146, s. 8.

${ }^{101}$ O wnętrzu modernistycznym. Rozmowa z artysta malarzem Natanem Reingewircem, „Nasz Przegląd" 8 (1930), nr 33, s. 9.

${ }^{102}$ Katalog wystawy Ireny i Natana Rajngewirców. Gobeliny, kilimy, meble, drzeworyty, druki. Stowo wstępne Anatola Sterna, styczeń, luty 1926, Żydowskie Towarzystwo Krzewienia Sztuk Pięknych, Warszawa [1926]. 
oraz w kolejnej, otwartej na przełomie 1930/31 r. ${ }^{103}$, małżonkowie pokazywali m.in. gobeliny, kilimy, meble, drzeworyty i druki, które spodobały się zarówno publiczności, jak i krytykom.

\section{Sztuka żydowska}

Czytając recenzje z wystaw, nietrudno zauważyć, że idea sztuki żydowskiej, sztuki „rodzimej” czy stylu żydowskiego powraca nie tylko jako element definiujący indywidualną twórczość artystów, lecz także jako czynnik wyróżniający sztukę żydowską rozważaną w kontekście narodowym. Tak opisywane były ekspozycje dawnych mistrzów: Leopolda Pilichowskiego, Maurycego Minkowskiego czy Jakuba Weinlesa, w których twórczości najważniejszy był temat żydowski, najczęściej odwołujący się do świąt lub tradycyjnego obrazu życia Żydów, tak pisano także o twórczości Reginy Mundlak.

Kariera Mundlak rozpoczęła się w początkach XX stulecia niezwykle obiecująco - od opieki, jaką nad „cudownym dziecka getta” roztoczył w Berlinie sławny malarz niemiecki Max Liebermann ${ }^{104}$. W dwudziestoleciu międzywojennym, kiedy Mundlak mieszkała w Warszawie, nadal widziała siebie jako portrecistkę świata tradycyjnego żydostwa. Także od strony formalnej jej sztuka pozostała bliska XIX-wiecznemu realizmowi i naturalizmowi. Nie chciała, być może nie umiała, wyjść poza zakreślone w młodości ramy swej twórczości. I pewnie dlatego wegetowała gdzieś na obrzeżach życia artystycznego jako przedstawicielka „sztuki paseistycznej, żyjącej wspomnieniami secesyjnej grafiki i Mehoffera" ${ }^{105}$, jak pisał w 1938 r. Strakun w recenzji z jedynej w międzywojniu warszawskiej wystawy artystki. Ta wspólna ekspozycja Mundlak i wychowanka jesziwy w Żarnowcu Bernarda Rolnickiego (1890-1942) była złożeniem hołdu sztuce przeszłości i jej symbolicznym pożegnaniem ${ }^{106}$.

${ }^{103}$ Była to wspólna wystawa Stanisławy Centnerszwerowej oraz Ireny i Natana Rajngewirców otwarta w dniach 7 grudnia 1930 - 8 stycznia 1931 r. Następna wystawa Rajngewirców odbyła się w Salonie Czesława Garlińskiego (25 listopada - 8 grudnia 1934 r.).

104 W 1902 r. w berlińskim czasopiśmie „Ost und West”, poświęconym sprawom żydowskim na wschodzie i zachodzie Europy, ukazał się list wybitnego grafika Efraima Mojżesza Liliena $\mathrm{z}$ apelem o pomoc finansową dla młodziutkiej artystki i wsparcie jej talentu - Efraim Lilien, Ein Offener brief (Juedische Maecene und Juedische Kunst), „Ost und West” 2 (1902), nr 2, szp. 109-114.

${ }^{105}$ Leon (Leopold) Strakun, Na antenie sztuki. Wystawa w Żyd. Tow. Krzewienia Sztuk Pięknych, „Nowy Głos” 2 (1938), nr 85, s. 4.

106 Otwarta w dniach 20 marca - 22 kwietnia 1938 r. Większość piszących o niej krytyków poświęciła pracom Mundlak co najwyżej krótki akapit - Michał Weinzieher, Regina 
Idea sztuki żydowskiej, pojmowana inaczej niż w pracach artystów z przełomu XIX i XX w., ważna była także dla twórców z kręgu awangardy żydowskiej - Henryka Berlewiego, Icchoka Vincenta Braunera, Henryka Barczyńskiego czy Marka Szwarca, a ich warszawskie wystawy omawiane były prawie wyłącznie w kontekście sztuki narodowej. Jedyną artystką z kręgu Jung Idysz, która miała własną wystawę w Żydowskim Towarzystwie Krzewienia Sztuk Pięknych ${ }^{107}$, była Pola Lindenfeld (18941942), znana pod pseudonimem Polin. Z Łodzi wyjechała wcześnie, już w 1919 r., do Niemiec. W maju 1922 r. wzięła udział w obradach Kongresu Międzynarodowej Unii Postępowych Artystów oraz w Wielkiej Wystawie Nowej Sztuki w Düsseldorfie ${ }^{108}$, na której pokazała rzeźby: Prorok, Matka, Krzyczacy, Zaduma I, Zaduma II. W 1924 r. artystka odbyła podróż do Włoch, Egiptu i Palestyny, by później osiąść na stałe w Paryżu ${ }^{109}$. Wtedy też zaczęła używać znaczącego pseudonimu: Polin (czyli skrótu pierwszych sylab swojego imienia i nazwiska, a zarazem hebrajskiej nazwy Polski).

Warto spojrzeć na dorobek Lindenfeld w świetle sztuki żydowskiej, zwłaszcza w kontekście dzieł jej kolegów - Braunera, Barczyńskiego czy Szwarca, dla których ważnym źródłem inspiracji była żydowska sztuka ludowa oraz Biblia. Twórczość Lindenfeld od początku była nie tyle żydowska, ile uniwersalna. Zarówno grafiki, publikowane w „Jung Idysz”, „Zdroju” czy „Tańczącym Ogniu”, jak i rzeźby - archaizujące, stylizowane,

Mundlak i Bernard Rolnicki, „Nasz Przegląd” 16 (1938), nr 94, s. 6. Mundlak wystawiała w Berlinie w 1930 r., miała też wystawy indywidualne w Łodzi (1924) i Wilnie (1939).

${ }_{107}$ Dina Matus, inna artystka z kręgu Jung Idysz, nie wystawiała w Warszawie od roku 1921, kiedy to na [I] Wystawie Prac Artystów Żydowskich razem z Idą Braunerówną pokazały albumy linoleorytów barwnych (w dziale „Grafika-zdobnictwo”), Katalog Wystawy Prac Artystów Żyd...., s. 13-14. Najprawdopodobniej były to ilustracje do tomów poetyckich (lub same tomiki): Braunerówny do Dawida Zytmana Ojf wajtkajtn krajzende fat ich, Matus do tomu Rahel Lipstein, Zwischen dem Abend und Morgenrot, obydwa wydane w $1921 \mathrm{r}$. w łódzkim wydawnictwie Achrid. Trzecim (ostatnim?) wydawnictwem oficyny Achrid jest tom poezji Chaima Krula, Himlen in opgrunt, z ilustracjami Estery Karp - zob. Izabela Powalska, Wokót „Tańczacego Ognia”. Kobiety artystki w grupie Jung Idysz, „Pamiętnik Sztuk Pięknych" 5 (2018), nr 13, s. 95-103.

${ }_{108}$ Henryk Berlewi, Międzynarodowa Wystawa w Düsseldorfie, „Nasz Kurier” 3 (1922), nr 209, s. 2; Jankiel Adler, Jidisze kinstler ojf der internacionale kunst-ojssztelung, „Hajnt” 15 (1922), nr 92, s. 5. Ani Berlewi, ani Adler nie wspomnieli o udziale Lindenfeld. Zob. też Jerzy Malinowski, Polska awangarda w Niemczech 1900-1933, [w:] Między Polska a światem. Od średniowiecza po lata II wojny światowej, red. Mieczysław Morka, Piotr Paszkiewicz, Warszawa 1993, s. 265-267; Lidia Głuchowska, „Międzynarodówka ducha” i inne utopie. Glossy do dziejów pewnego kongresu, [w:] Awangarda i państwo, [kat. wystawy], red. Dorota Monkiewicz, Muzeum Sztuki w Łodzi, Łódź 2018, s. 143-154.

${ }^{109}$ Przed dzisiejszym otwarciem wystawy w Żyd. Tow. Krzewienia Sztuk Pięknych. Pola Lindenfeld. S. Trachter, „Nasz Przegląd” 8 (1930), nr 47, s. 9. 
monumentalne kobiece akty i głowy - odchodziły od obiegowego rozumienia sztuki żydowskiej. Dla swej twórczości rzeźbiarka szukała źródeł poza artystyczną tradycją żydowską (il. 8).

Jedynie Lindenfeld wydobyła się z cienia kolegów, choć - jak wskazuje recepcja jej twórczości w Polsce - nie do końca udało się jej zaistnieć w tutejszych kręgach artystycznych. Wystawa w Warszawie odbywała się jednocześnie z pokazem dzieł lubelsko-paryskiego malarza Symchy Trachtera ${ }^{110}$. I to przede wszystkim jego twórczość przyciągnęła uwagę krytyki. Obecność rzeźbiarki odnotowywano najczęściej jednym gładkim zdaniem, jak to Tytusa Czyżewskiego: „Obok tej wystawy [tj. Trachtera - R.P.] także interesująca wystawa rzeźb pani Lindenfeld. Niektóre głowy w marmurze bardzo piękne. Dużo kultury i technicznej umiejętności”"111. Być może zdecydował o tym fakt, że wystawa Lindenfeld-Polin nie była przedstawieniem się artystki-Żydówki, lecz współczesnej rzeźbiarki, której sztuka z jednej strony odwoływała się do przeszłości (krytycy przywoływali rzeźbę romańską i gotycką), z drugiej zaś widziano w niej inspirację Wschodem i ta mieszanka pozwalała jej stworzyć oryginalny język nowoczesnej rzeźby.

Przykład wystawy Lindenfeld, która przeszła prawie bez echa, jak i nieobecność na ekspozycjach ŻTKSP innych artystek z kręgu Jung Idysz wskazują, że ich drugorzędna pozycja w grupie - Braunerówna była tam redaktorką almanachu, a na jego łamach ukazały się jedynie prace Lindenfeld - przenosiła się na marginalizację ich dojrzałej twórczości.

W świecie sztuki kobiety musiały walczyć o przestrzeń dla swojej twórczości. Ida Braunerówna, siostra Icchoka Braunera, wystawiała w Warszawie w grudniu 1929 r., jednak nie w ŻTKSP, lecz w cieszącym się renomą Salonie Czesława Garlińskiego. Być może dlatego artystka wybrała to miejsce na swą pierwszą indywidualną wystawę w stolicy, możliwe jest też, iż nie udało się zorganizować tej ekspozycji w salonach ŻTKSP. Niewiele pisano o tym pokazie, jedynie Mieczysław Wallis komentował ją w typowym dla siebie lekceważąco-drwiącym, jeśli chodzi o twórczość kobiet ${ }^{112}$, stylu:

110 Wystawa Symchy Trachtera i Poli Lindenfeldówny otwarta była w dniach 16 lutego - 14 marca 1930 r. Nie zachował się katalog pokazu Lindenfeld. Wiemy natomiast, jakie prace pokazała rzeźbiarka w Łodzi w kwietniu tego roku: Wystawa zbiorowa prac: Mieczysława Siemińskiego, Eustachego Pietkiewicza, Mariana Strońskiego, Grupy Artystów Plastyków „Zwornik”, oraz bieżaca: Poli Lindenfeldówny, Zenobiusza Poduszko, Marka Szapiro i Gustawa Szulca, [kat. wystawy], Miejska Galeria Sztuki, Łódź 1930.

111 Tytus Czyżewski, Trzy wystawy zbiorowe. Władystaw Roguski - S. Trachter - Grabowski, „Kurier Polski” 33 (1930), nr 53, s. 4.

${ }_{112}$ Zob. np. Mieczysław Wallis, Sztuki plastyczne. Wystawa grupy artystek malarek „Kolor”, „Robotnik” 35 (1929), nr 26, s. 2. 


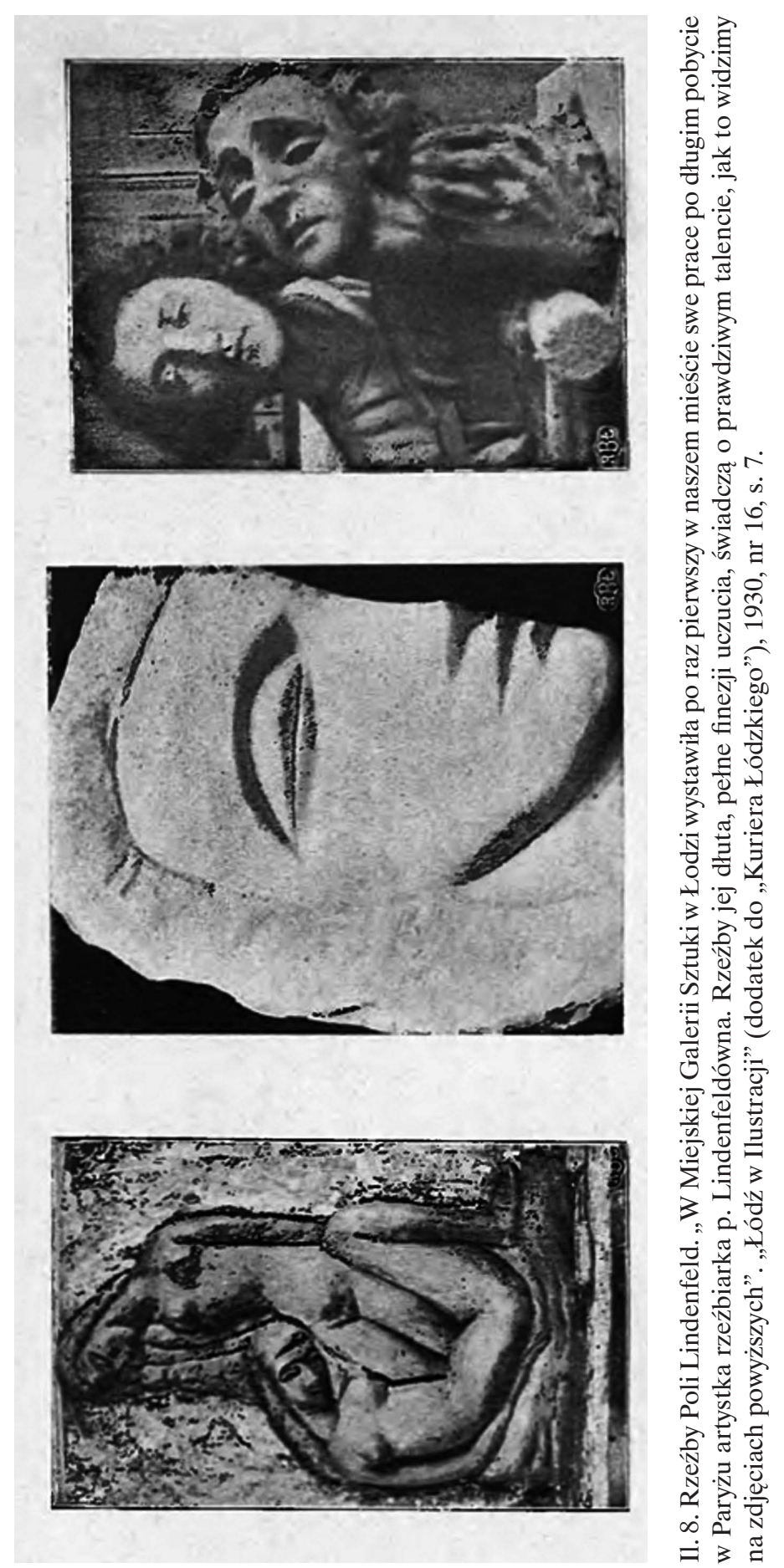


P. Ida Braunerówna rzeźbi główki, posążki kobiece, medaliony i kamee z drewna. Utwory jej są przeważnie tak drobne, iż sama twórczyni nazywa je „rzeźbami - miniaturami”. [...] Można by jej zarzucić to, że nie uwydatnia ona należycie charakteru tworzywa, oraz to, że mimo drobnych rozmiarów utwory jej nie są bynajmniej utrzymane w stylu miniaturowym, lecz, przeciwnie, są pomyślane w wielkich, syntetycznych bryłach. [...] Niektóre jej posążki, wykonane w kamieniu, w większym formacie, wyobrażam sobie zupełnie dobrze na tle jakiegoś ogrodu i parku ${ }^{113}$.

Kilka dni później Braunerówna pokazała niektóre z tych prac w Salonie Dorocznym ŻTKSP ${ }^{114}$. Należy żałować, że prawie żadne z jej dzieł nie przetrwało nawet na fotografii i że możemy się odwołać jedynie do opinii niezbyt obiektywnego w tym wypadku krytyka.

\section{Lata trzydzieste}

Od początku lat trzydziestych w wystawach ŻTKSP i SŻAPwP brały też udział studentki i absolwentki uczelni artystycznych, m.in.: Resia Ajnsztajnówna (później Resia Schor), Gela Seksztajn, Halina Landau, Ludka Pinkusewicz (Lutka Pink), Bella Natansonowa, Rachela Kohnówna, Eugenia Rostan (Eugenia Rozenfarb), Antonina Richterówna, Rega Szenbrun, Stella Amalia Miller (Mirels), Rojza Zylberminc. Żadna z nich nie miała jednak w salonach Towarzystwa ekspozycji indywidualnej. By zaistnieć, musiały brać sprawy w swoje ręce i samodzielnie organizować pokazy, jak zrobiła to kiedyś Ida Brauner. W 1937 r. Ludka Pinkusewicz (1906-1998), niedawna studentka warszawskiej ASP, urządziła wystawę w galerii Związku Zawodowego Polskich Artystów Plastyków. Od razu szerzej pisano o jej twórczości ${ }^{115}$. Podobnie było w przypadku lubelskiej artystki Miry Zylowej (to pseudonim Miry Silberszlagowej, ?-?), o której pracach pokazanych w 1935 r. na Salonie Zimowym ŻTKSP najwięcej przeczytamy w dzienniku „Lubliner Tugblat”116. Gdyby Zylowa, która wystawiała w ŻTKSP od roku 1931, nie zorganizowała zimą 1936 r. wystawy w dawnych salonach Philipsa przy ul. Mazowieckiej 9 (a wstępu do katalogu

113 Mieczysław Wallis, Sztuki plastyczne. Zofia Wegierkowa, Ida Braunerówna i Halina Frojndówna. [...], „Robotnik” 35 (1929), nr 364, s. 3.

1145 stycznia - 14 lutego 1930 r. - Salon Doroczny ŻTKSP. Nie zachował się katalog wystawy. Zob. Apenszlakowa, Salon zimowy w Żyd. Tow...., „Nasz Przegląd” 8 (1930), nr 17, s. 6.

115 Michał Weinzieher, Ostatnie wystawy. Ludwika Pinkusiewicz - Sasha Blonder, „Nasz Przegląd" 15 (1937), nr 144, s. 6; Leopold Strakun, Z wystaw. Wystawa obrazów Ludwiki Pinkusiewicz, „Ster” 1 (1937), nr 14, s. 7; Mieczysław Wallis, Wystawy, „Wiadomości Literackie” 14 (1937), nr 25, s. 6.

${ }^{116}$ Mira Zilowa fun Lublin ojf der ojssztelung in der jidiszer kunst-gezelszaft in Warsze, „Lubliner Tugblat" 17 (1935), nr 300, za: Adam Kopciowski, Wos hert zich in der prowinc? Prasa żydowska na Lubelszczyźnie i jej największy dziennik „Lubliner Tugblat”, Lublin 2015, s. 452. 
nie napisał Tytus Czyżewski), niewiele dziś wiedzielibyśmy o tej interesującej artystce ${ }^{117}$. Dopiero po tym pokazie Mieczysław Sterling powitał „Nowy talent kobiecy”118, a inni krytycy zwrócili uwagę na jej malarstwo ${ }^{119}$. Zylowa wystawiała później w Paryżu.

Niestety, interesujące obrazy Zylowej, podobnie jak prace wszystkich wymienionych dotąd artystek (z wyjątkiem Geli Seksztajn, której przedwojenna twórczość ocalona została w Archiwum Ringelbluma ${ }^{120}$ ), znamy jedynie z nielicznych czarno-białych fotografii w prasie czy w katalogach wystaw. Większość artystek została zamordowana w czasie II wojny światowej, ich śmierć w Zagładzie była też zniszczeniem ich twórczego dorobku.

\section{Podsumowanie}

Udział kobiet - artystek i miłośniczek sztuki - w żydowskim życiu artystycznym w Warszawie trudno uznać za znaczący, zwłaszcza w przypadku tej drugiej grupy. W ŻTKSP zadania kobiet ograniczały się do działań społecznych, organizacyjnych, o fasadowym (jak Bale Sztuki Żydowskiej) lub charytatywnym charakterze. W sferze publicznej kobiety działały więc w obszarach akceptowanych przez tradycyjną społeczność. Natomiast ich realny wpływ na kierunki rozwoju Towarzystwa czy decyzje o programie wystaw był minimalny.

Niewiele bardziej widzialne (i słyszalne) były artystki. Mimo stale rosnącej liczby kobiet uczestniczących w wystawach tylko siedem zasłużyło na pokaz indywidualny. Nie wiemy zresztą, dlaczego to właśnie je wybrano. Możemy domniemywać, że w przypadku Mundlak i Centnerszwerowej decydowała ich pionierska działalność na niwie sztuki żydowskiej w Warszawie, inne opromieniała sława Paryża. Trzeba zresztą zauważyć, że te wystawy pasowały do linii programowej ŻTKSP, w której „porzucono”

117 Wystawa obrazów Miry Zylowej. Luty 1936, [kat. wystawy], wstęp Tytus Czyżewski, Warszawa [1936].

${ }_{118}$ Mieczysław Sterling, Nowy talent kobiecy. Wystawa M. Zylowej, „Kurier Poranny” 60 (1936), nr 53, s. 6.

119 Wacław Husarski, Wystawy warszawskie, „Czas” 88 (1936), nr 53, s. 8; tenże, Wystawy, „Wiadomości Literackie” 13 (1936), nr 9, s. 7; Tytus Czyżewski, Stykowie w Zachęcie i Mira Zylowa, „Kurier Polski” 39 (1936), nr 54, s. 3; stc [Stanisław Ciechomski], Obrazy Miry Zylowej, „Myśl Polska” 1 (1936), nr 3, s. 8; Ciekawy debiut malarski, „Nasz Przegląd” 14 (1936), nr 50, s. 14; Michał Weinzieher, Wystawa Miry Zylowej. Salony Philipsa - Mazowiecka 9, „Nasz Przegląd” 14 (1936), nr 55, s. 14.

${ }^{120}$ Archiwum Ringelbluma. Konspiracyjne Archiwum Getta Warszawy, t. 4: Życie i twórczość Geli Seksztajn, oprac. Magdalena Tarnowska, Warszawa 2011. 
ideę sztuki żydowskiej jako odrębnej pod względem stylu, formy czy tematu, wspierano natomiast swobodny rozwój artystyczny twórców nawiązujących do sztuki najnowszej, z prezentacji tak różnorodnej twórczości uczyniono zaś narzędzie do wprowadzenia społeczności żydowskiej w nowoczesny świat, we współczesną, polską i światową kulturę i sztukę.

Być może ta niewielka obecność kobiet wynikała nie tylko z polityki Towarzystwa. Wiele artystek pochodzących z rodzin żydowskich (prawie) nigdy nie wystawiało na żydowskich wystawach. Latem 1924 r., jeszcze przed wstąpieniem do Akademii Sztuk Pięknych ${ }^{121}$, Julia Ringel-Keilowa (1902-1943) na 9 Wystawie Zbiorowej ŻTKSP pokazała prace: Główka, Myśl, Uścisk smutku ${ }^{122}$. Był to najprawdopodobniej jej debiut i - jak się okazało - był to także pierwszy i ostatni raz, kiedy zaprezentowała się w żydowskim salonie sztuki. Franciszka Themerson (1907-1988), córka Jakuba Weinlesa, która (obok swej siostry Marii Weinles-Chaykinowej) jako piętnastolatka zadebiutowała na IV Żydowskiej Wystawie Sztuki ${ }^{123}$, później nie brała już udziału w wystawach Towarzystwa. Malarki, koleżanki z warszawskiej Akademii: Elżbieta Hirszberżanka (Malinowska) (1899 - po 1960), Gizela Hufnaglówna (Klimaszewska-Arctowa) (1903-1997) i Mery Litauer-Schneider (1900-1992), które stworzyły jedyną w dwudziestoleciu kobiecą grupę artystyczną „Kolor” ${ }^{24}$, nigdy nie brały udziału w żydowskim życiu artystycznym. Ich wspólne wystawy odbywały się w lokalu Związku Zawodowego Artystów Plastyków (1929), w Salonie Czesława Garlińskiego (1930) ${ }^{125}$ oraz w Instytucie Propagandy Sztuki (1933) ${ }^{126}$. Choć działalność grupy trwała krótko, to pomogła artystkom zdefiniować swą artystyczną tożsamość, rozpocząć karierę, pokazać się publiczności.

${ }^{121}$ Ringel-Keilowa rozpoczęła studia w 1925 r., Archiwum ASP, Akta studentów sprzed 1939, nr 453.

1229 Wystawa Zbiorowa. Czerwiec - Lipiec 1924, Żydowskie Towarzystwo Krzewienia Sztuk Pięknych, Warszawa [1924], poz. kat. 88 (Gtówka), 89 (Myśl), 90 (Uścisk smutku). Udział Ringel-Keilowej przeszedł niezauważony, jedynie Leopold Strakun napisał: „Rzeźby Kajlowej (Myśl) są banalne”. Leopold Strakun, Żydowska Wystawa Sztuki, „Nasz Przegląd" 2 (1924), nr 165, s. 4.

${ }^{123}$ Katalog IV-ej Wystawy obrazów i rzeźb, kwiecień-maj 1922, Warszawa [1922].

${ }^{124}$ Renata Piątkowska, Malarki warszawskiej grupy „Kolor”, „Aspiracje” 2009, s. 2-9; Agnieszka Szewczyk, Grupa Kolor, [w:] Sztuka wszędzie. Akademia Sztuk Pięknych w Warszawie 1904-1944, [kat. wystawy], red. Jola Gola, Maryla Sitkowska, Agnieszka Szewczyk, Warszawa 2012, s. 152-153.

${ }^{125}$ Wystawa Grupy Art. Mal. p.n. „Kolor”: od 20.V do 2.VI.1930, wstęp Mieczysław Sterling, [kat. wystawy], Salon Sztuki Czesława Garlińskiego, Warszawa [1930].

${ }^{126}$ Katalog Wystawy Grupy Plastyków Nowoczesnych. Konstantego Mackiewicza. Grupy „Kolor”. Kazimierz Dolny w malarstwie, Instytut Propagandy Sztuki, 10 czerwca - 10 lipca 1933, Warszawa [1933]. 
Co decydowało o takich wyborach? Odpowiedzi na to pytanie zapewne nie poznamy, możemy jednak się zastanowić nad powodami ich decyzji. O udziale w wystawach ŻTKSP przesądzić mogły względy pragmatyczne początkującym artystom łatwiej było wystawić w dorocznym Salonie ŻTKSP niż na przykład w Instytucie Propagandy Sztuki. Jednak prestiż tych salonów był niezbyt wysoki, co z pewnością nie ułatwiało dalszej kariery. Ponadto w przypadku pochodzących z rodzin zasymilowanych Ringel-Keilowej i malarek z grupy „Kolor” mocno akcentowana nacjonalistyczna orientacja Towarzystwa mogła być zbytnim ograniczeniem ich życiowych i artystycznych wyborów. Natomiast dla Themerson linia programowa Towarzystwa była zbyt zachowawcza, zamknięta na awangardowe poszukiwania, które interesowały ją w latach trzydziestych.

Zebrane tu okruchy informacji o kobietach w żydowskim życiu artystycznym międzywojennej Warszawy potwierdzają fakt, zauważalny także w innych dziedzinach, iż mimo postępującej modernizacji społeczności żydowskiej w II Rzeczypospolitej ugruntowany od wieków w judaizmie system patriarchalny wciąż sprawiał, że kobiety nie były traktowane jako równorzędne partnerki ${ }^{127}$. Lecz widać też wyraźnie, że w okresie międzywojennym kobiety coraz odważniej wkraczały na pole sztuki. Przestawały negocjować swą obecność w życiu artystycznym, po prostu w nim uczestniczyły. Żadnej z artystek-Żydówek nie udało się osiągnąć sukcesu Zofii Stryjeńskiej ${ }^{128}$, ale niektóre z nich zdobyły mocną pozycję w świecie sztuki, jak Stanisława Centnerszwerowa w Warszawie czy Pola Lindenfeld w Paryżu.

Wyeksponowanie kobiet-artystek-Żydówek w świecie sztuki dwudziestolecia międzywojennego wciąż nie dla wszystkich jest uzasadnione, choć obecnie wiemy, że spojrzenie z punktu widzenia kobiety (artystki i miłośniczki) pozwala nie tylko na zobaczenie rzeczywistego miejsca kobiet w żydowskim życiu artystycznym międzywojennej Warszawy, lecz także na rozpoczęcie nowych wątków, jak na przykład „manifestowania się płci” ${ }^{129}$ w twórczości artystek-Żydówek.

127 Joanna Lisek, Kol isze - glos kobiet w poezji jidysz (od XVI w. do 1939 r.), Sejny 2019, s. $16-18$.

${ }^{128}$ Sosnowska, Poza kanonem..., s. 149-179.

129 Tamże, s. 11. Wydaje się, że zwłaszcza twórczość Poli Lindenfeld, mimo iż znana prawie wyłącznie z reprodukcji, wymaga wnikliwego zbadania. 


\section{Bibliografia}

\section{1. Źródła archiwalne}

Archiwum Akademii Sztuk Pięknych w Warszawie

Akta studentów sprzed 1939, numery 256 i 453.

Księga Protokołów Rady Gtównej Szkoły Sztuk Pięknych w Warszawie.

Archiwum Instytutu Sztuki PAN

Archiwum Instytutu Propagandy Sztuki, Zbiory Specjalne, sygn. 70.

Ziembińska Ewa, Sara Lipska. Artystka wszechstronna, Warszawa 2020 (mps, praca doktorska napisana pod kierunkiem prof. dr hab. Joanny M. Sosnowskiej w Instytucie Sztuki Polskiej Akademii Nauk).

Biblioteka Narodowa

Afisz: „Bal maskowy sztuki i prasy żydowskiej Związku Żydowskich Literatów i Dziennikarzy", Warszawa 1923, sygn. DŻS IK 2f.

Afisz wystawy Zofii Bornstein w Żydowskim Towarzystwie Krzewienia Sztuk

Pięknych, Warszawa 1927, sygn. DŻS IK 2f.

Muzeum Historii Żydów Polskich POLIN

Album Artysty I, Archiwum Marka i Eugenii Szwarców, nlb.

Tel Aviv Museum of Art (TAMA), The Museum Archive

List Polsko-Palestyńskiej Izby Handlowej z 17 kwietnia 1936, sygn. 283, poz. 2.

\section{2. Źródła opublikowane}

\section{Prasa}

„Czas” 1936.

„Ewa” 1928-1932.

„Hajnt” 1922, 1936.

„Kurier Polski” 1930, 1936.

„Kurier Poranny” 1936.

„Literarisze Bleter” 1926, 1927.

„Łódźw Ilustracji” (dodatek do „Kuriera

Łódzkiego") 1930.

„Myśl Polska” 1936.

„Nasz Przegląd” 1923-1939.

„Nasz Przegląd Ilustrowany” 1927-1932.

„Nowy Dziennik” 1930.

„Nowy Głos” 1938.

„Ost und West” 1902.

„Polska Zbrojna” 1934.

„Robotnik” 1929.

„Ster” 1937.

„Nasz Kurier” 1921, 1922.

„Wiadomości Literackie” 1936, 1937.

\section{Inne źródła drukowane}

9 Wystawa Zbiorowa. Czerwiec - Lipiec 1924, Żydowskie Towarzystwo Krzewienia Sztuk Pięknych, Warszawa [1924].

XVII Wystawa Prac Dekoracyjnych Alicji Hohermann. Październik 1925 Listopad, Żydowskie Towarzystwo Krzewienia Sztuk Pięknych, Warszawa [1925].

Archiwum Ringelbluma. Konspiracyjne Archiwum Getta Warszawy, t. 4: Życie i twórczość Geli Seksztajn, oprac. Magdalena Tarnowska, Warszawa 2011. Arciszewska Tea, Miriaml, Pariz 1959.

Fragmented Mirror: Exhibition of Jewish Artists, Berlin 1907, red. Batsheva Goldman-Ida, [kat. wystawy], Tel Aviv Museum of Art, Tel Aviv 2009. 
Katalog IV-ej Wystawy obrazów i rzeźb, kwiecień-maj 1922, Warszawa [1922].

Katalog Wystawy Grupy Plastyków Nowoczesnych. Konstantego Mackiewicza. Grupy „Kolor”. Kazimierz Dolny w malarstwie, Instytut Propagandy Sztuki, 10 czerwca 10 lipca 1933, Warszawa [1933].

Katalog wystawy Ireny i Natana Rajngewirców. Gobeliny, kilimy, meble, drzeworyty, druki. Stowo wstępne Anatola Sterna, styczeń, luty 1926, Żydowskie Towarzystwo Krzewienia Sztuk Pięknych, Warszawa [1926].

Katalog Wystawy Prac Artystów Żyd. Warszawa Gmina Lato 1921, Warszawa [1921]. Lista adwokatów Okręgu Sądu Apelacyjnego w Warszawie (okrąg Izby Adwokackiej Warszawskiej) na dzień 15 grudnia 1938 r., Warszawa 1938.

Mortkowicz-Olczakowa Hanna, Bunt wspomnień, Warszawa 1961.

Salon Doroczny LXXXVII. Żydowskie Towarzystwo Krzewienia Sztuk Pięknych, [kat. wystawy], Warszawa [1938].

Singer Isaac Bashevis, Przyjaciel domu, [w:] tenże, Śmierć Matuzalema i inne opowiadania, tłum. Maria Olejniczak-Skarsgård, Warszawa 2006.

Sprawozdanie z budowy i opis gmachu 1928-1936, Komitet Budowy Gmachu Głównej Biblioteki Judaistycznej przy Wielkiej Synagodze w Warszawie, Komisja Techniczna, Warszawa 1936.

Statut Żydowskiego Towarzystwa Krzewienia Sztuk Pięknych w Warszawie, Warszawa 1924.

Świadectwa obecności. Polskie życie artystyczne we Francji w latach 1900-1939.

Diariusz wydarzeń z wyborem tekstów, cz. 2: Lata 1922-1929, wybór, oprac. i wprowadzenie Anna Wierzbicka, Warszawa 2015.

Wystawa Grupy Art. Mal. p.n. „Kolor”: od 20.V do 2.VI.1930, wstęp Mieczysław Sterling, [kat. wystawy], Salon Sztuki Czesława Garlińskiego, Warszawa [1930]. Wystawa obrazów Miry Zylowej. Luty 1936, [kat. wystawy], wstęp Tytus Czyżewski, Warszawa [1936].

Wystawa p.n. „Estetyka w życiu codziennem”. LXVI, wrzesień 1932, Żydowskie Towarzystwo Krzewienia Sztuk Pięknych, [kat. wystawy], Warszawa [1932].

Wystawa pośmiertna prac b. p. Józefa Seidenbeutla. Katalog wydany i ułożony przez M. i E. Seidenbeutlów, Warszawa [1923].

Wystawa zbiorowa prac: Mieczystawa Siemińskiego, Eustachego Pietkiewicza, Mariana Strońskiego, Grupy Artystów Plastyków „Zwornik”, oraz bieżąca: Poli Lindenfeldówny, Zenobiusza Poduszko, Marka Szapiro i Gustawa Szulca, [kat. wystawy], Miejska Galeria Sztuki, Łódź 1930.

\section{Opracowania}

Arciszewska Tea, I. L. Perec mont zajn teater (fun majne zichrones un refleksn), [w:] Almanach. Arojgegebn durch Farajn fun Jidiszer Literatn un Żurnalistn in Frankrajch, Pariz 1955.

Bacon Gershon, Mieses Józef, [w:] The YIVO Encyclopedia of Jews in Eastern Europe, red. Gershon David Hundert, YIVO | Mieses, Józef (yivoencyclopedia.org) [dostęp: 12 sierpnia 2021].

Borzymińska Zofia, Lewin Gerszon, [w:] Polski słownik judaistyczny. Dzieje. Kultura. Religia. Ludzie, red. Zofia Borzymińska, Rafał Żebrowski, Warszawa 2003, t. 2. 
Brubaker Rogers, Nacjonalizm inaczej. Struktura narodowa i kwestie narodowe w nowej Europie, tłum. Jan Łuczyński, Warszawa-Kraków 1998.

Czy wiesz kto to jest?, red. Stanisław Łoza, Warszawa 1938.

Fuks Marian, Mieses Józef, [w:] Polski Słownik Biograficzny, t. 21, red. Emanuel Rostworowski, Wiesława Albrecht i in., Wrocław-Warszawa 1976.

Geller Aleksandra, ,Literarisze Bleter” (1924-1939), [w:] Studia z dziejów trójjęzycznej prasy żydowskiej na ziemiach polskich $(X I X-X X$ w.), red. Joanna Nalewajko-Kulikov, Warszawa 2012.

Gerber Rafał, Muzeum im. Mathiasa Bersohna przy Wyzn. Gminie Żydowskiej w Warszawie, Warszawa 1939.

Głuchowska Lidia, „Międzynarodówka ducha” i inne utopie. Glossy do dziejów pewnego kongresu, [w:] Awangarda i państwo, [kat. wystawy], red. Dorota Monkiewicz, Muzeum Sztuki w Łodzi, Łódź 2018.

Godlewska Joanna, Polski Żyd. Jakub Apenszlak jako krytyk teatralny, „Pamiętnik Teatralny" 41 (1992), z. 1-4.

Konstantynów Dariusz, „Sztuka żydowska”. O jednym z pojęć nacjonalistycznej krytyki artystycznej w Polsce międzywojennej, „Kwartalnik Historii Żydów” 65 (2016), nr 2.

Kopciowski Adam, Wos hert zich in der prowinc? Prasa żydowska na Lubelszczyźnie i jej największy dziennik „Lubliner Tugblat”, Lublin 2015.

Kubaszewska Hanna, Makowska Urszula (uzup.), Natanson (Natansonowa) Bella (Bela), [w:] Słownik artystów polskich i obcych w Polsce działajacych: malarze, rzeźbiarze, graficy, t. 6, red. Katarzyna Mikocka-Rachubowa, Małgorzata Biernacka, Warszawa 1998.

Landau-Czajka Anna, Polska to nie oni. Polska i Polacy w polskojęzycznej prasie żydowskiej II Rzeczypospolitej, Warszawa 2015.

Lisek Joanna, Kol isze - głos kobiet w poezji jidysz (od XVI w. do 1939 r.), Sejny 2019.

Livnat Aviv, Far undzere kinstler: Tea Arciszewska and the Jewish Artists, [w:] Art in Jewish Society, red. Jerzy Malinowski, Renata Piątkowska, Małgorzata Stolarska-Fronia, Tamara Sztyma, Warszawa-Toruń 2016.

Makowska Urszula, Ogrody Abrahama Ostrzegi, „Pamiętnik Sztuk Pięknych” 4 (2017), nr 12.

Malinowski Jerzy, Malarstwo i rzeźba Żydów polskich w XIX i XX wieku, Warszawa 2000.

Malinowski Jerzy, Polska awangarda w Niemczech 1900-1933, [w:] Między Polska a światem. Od średniowiecza po lata II wojny światowej, red. Mieczysław Morka, Piotr Paszkiewicz, Warszawa 1993.

Malinowski Jerzy, Brus-Malinowska Barbara, W kręgu École de Paris. Malarze żydowscy z Polski, Warszawa 2007.

Molisak Alina, Zionism in Polish, or on a Few of Jakub Appenszlak's Texts, [w:] Polish and Hebrew Literature and National Identity, red. Alina Molisak, Shoshana Ronen, Warszawa 2010.

Piątkowska Renata, Jakub Apenszlak jako współtwórca Żydowskiego Towarzystwa Krzewienia Sztuk Pięknych, „Midrasz” 14 (2010), nr 6. 
Piątkowska Renata, Malarki warszawskiej grupy „Kolor”, „Aspiracje” 2009.

Piątkowska Renata, „Na palecie kobiecej”. Stanisława Centnerszwerowa i Regina Mundlak - dwie perspektywy twórcze, [w:] Nieme dusze? Kobiety w kulturze jidysz, red. Joanna Lisek, Wrocław 2010.

Piątkowska Renata, Studenci wyznania mojżeszowego w warszawskiej Akademii Sztuk Pięknych (1923-1939). Studia - debiuty - kariery, „Biuletyn Historii Sztuki” 77 (2015), nr 4.

Plach Eva, Feminism and Nationalism on the Pages of "Ewa: Tygodnik" 1928-1933, „Polin” 18 (2005).

Posłowie i senatorowie Rzeczypospolitej Polskiej 1919-1939. Słownik biograficzny, t. 3, oprac. Piotr Majewski, red. Grzegorz Mazur, Warszawa 2005.

Powalska Izabela, Wokót „Tańczącego Ognia”. Kobiety artystki w grupie Jung Idysz, „Pamiętnik Sztuk Pięknych” 5 (2018), nr 13.

Rawicz Melech, Majn leksikon, t. 3, Montreal 1958.

Rawicz Melech, Tłomackie 13 (Farejn fun Jidisze Literatn un Żurnalistn in Warsze), [w:] tenże, Dos majse buch fun majn lebn. Jorn in Warsze 1921-1934, tłum. Magdalena Ruta, Tel Aviv 1975.

Rogozik Janina Katarzyna, „Nasz Przeglad”: między „hajntyzmem” a „mechesyzmem”, „Zeszyty Prasoznawcze” 40 (1997), nr 1-2; 40 (1997), nr 3-4.

Sandel Józef, Stanisława Centnerszwerowa, [w:] Słownik artystów polskich i obcych w Polsce działajacych: malarze, rzeźbiarze, graficy, t. 1, red. Jolanta Maurin-Białostocka i in., Warszawa 1971.

Sosnowska Joanna, Poza kanonem. Sztuka polskich artystek 1880-1939, Warszawa 2003.

Steffen Katrin, Jüdische Polonität: Ethnizität und Nation im Spiegel der polnischsprachigen jüdischen Presse 1918-1939, Göttingen 2004.

Steffen Katrin, „Polska - to takíe my!’. Prasa polsko-żydowska (1918-1939), [w:] Studia $z$ dziejów trójjęzycznej prasy żydowskiej na ziemiach polskich (XIX-XXw.), red. Joanna Nalewajko-Kulikov, Warszawa 2012.

Szabłowska-Zaremba Monika, Dziennikarki międzywojennej prasy polsko-żydowskiej (wstępne rozpoznanie), „Archiwum Emigracji” 17 (2014), z. 1-2.

Szabłowska-Zaremba Monika, Portret syjonistki z łam „Ewy”, tygodnika dla pań (1928-1933), [w:] Żydzi wschodniej Polski, seria 3: Kobieta żydowska, red. Anna Janicka, Jarosław Ławski, Barbara Olech, Białystok 2015.

Szarejko Piotr, Słownik lekarzy polskich XIX wieku, t. 4, Warszawa 1997.

Szewczyk Agnieszka, Grupa Kolor, [w:] Sztuka wszędzie. Akademia Sztuk Pięknych w Warszawie 1904-1944, red. Jola Gola, Maryla Sitkowska, Agnieszka Szewczyk, [kat. wystawy], Warszawa 2012.

Tarnowska Magdalena, Feliks Frydman, [w:] Polski słownik judaistyczny. Dzieje. Kultura. Religia. Ludzie, red. Zofia Borzymińska, Rafał Żebrowski, Warszawa 2003, t. 1.

Trunk Jechiel Jeszaja, Pojln. Zichrojnes un bilder, Nju Jork 1944-1953, t. 5.

Umińska Bożena, Postać z cieniem. Portrety Żydówek w polskiej literaturze od końca XIX wieku do 1939 roku, Warszawa 2001. 
Wapiński Roman, Narodowa Demokracja, 1893-1939. Ze studiów nad dziejami myśli nacjonalistycznej, Wrocław 1980.

Weiser Keith (Kalman), Jewish People, Yiddish Nation: Noah Prylucki and the Folkists in Poland, Toronto 2011.

Wierzbicka Anna, Regina Mundlak, [w:] Słownik artystów polskich i obcych w Polsce działających: malarze, rzeźbiarze, graficy, t. 5, red. Janusz Derwojed, Warszawa 1993.

Żebrowski Rafał, Koerner Mojżesz, [w:] Polski słownik judaistyczny. Dzieje. Kultura. Religia. Ludzie, red. Zofia Borzymińska, Rafał Żebrowski, Warszawa 2003, t. 1. Żebrowski Rafał, Żydowska Gmina Wyznaniowa w Warszawie 1918-1939. W kręu polityki, Warszawa 2012.

Renata Piatkowska

Polski Instytut Studiów nad Sztuką Świata Muzeum Historii Żydów Polskich POLIN rpiatkowska@op.pl 